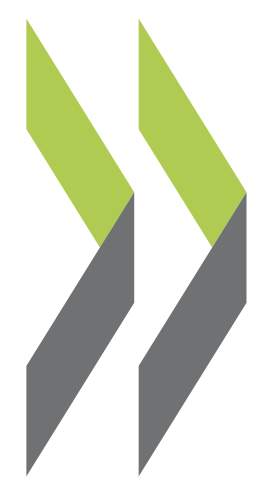

OECD Social, Employment and Migration Working Papers No. 116

\title{
Cooking, Caring and Volunteering: Unpaid Work Around the World
} Veerle Miranda 
Organisation de Coopération et de Développement Économiques

Organisation for Economic Co-operation and Development

20-Sep-2011

DIRECTORATE FOR EMPLOYMENT, LABOUR AND SOCIAL AFFAIRS

English - Or. English

EMPLOYMENT, LABOUR AND SOCIAL AFFAIRS COMMITTEE

Cancels \& replaces the same document of 25 February 2011

OECD SOCIAL, EMPLOYMENT AND MIGRATION WORKING PAPERS Nº 116

COOKING, CARING AND VOLUNTEERING: UNPAID WORK AROUND THE WORLD

Veerle Miranda

JEL classification : D13, J22, J13, J16, D63

Veerle Miranda, contact details : veerle.miranda@oecd.org; tel. + 33145241873.

All Social, Employment and Migration Working Papers are now available through the OECD website at www.oecd.org/els/workingpapers 


\title{
DIRECTORATE FOR EMPLOYMENT, LABOUR AND SOCIAL AFFAIRS
}

www.oecd.org/els

\section{OECD SOCIAL, EMPLOYMENT AND MIGRATION WORKING PAPERS}

\author{
www.oecd.org/els/workingpapers
}

This series is designed to make available to a wider readership selected labour market, social policy and migration studies prepared for use within the OECD. Authorship is usually collective, but principal writers are named. The papers are generally available only in their original language - English or French - with a summary in the other.

Comment on the series is welcome, and should be sent to the Directorate for Employment, Labour and Social Affairs, 2, rue André-Pascal, 75775 PARIS CEDEX 16, France.

The opinions expressed and arguments employed here are the responsibility of the author(s) and do not necessarily reflect those of the OECD.

Applications for permission to reproduce or translate all or part of this material should be made to:

\author{
Head of Publications Service \\ OECD \\ 2, rue André-Pascal \\ 75775 Paris, CEDEX 16 \\ France
}

Copyright OECD 2010 
DELSA/ELSA/WD/SEM(2011)1

\section{ACKNOWLEDGEMENTS}

This paper serves as a background document for the special focus chapter on unpaid work in $O E C D$ Society at a Glance 2011. Veerle Miranda is Economist at the Social Policy Division of the OECD Directorate for Employment, Labour and Social Affairs. The author would like to express her gratitude to Simon Chapple, John Martin, Monika Queisser and Willem Adema for their valuable comments. This paper draws on many time-use surveys collected for the 2009 edition of OECD Society at a Glance by David Jonathan Gonzalez Villascan, who was a consultant at the OECD at the time. The OECD is also grateful to the statistical agencies responsible for the time-use surveys included in this paper for the data and valuable clarifications on the surveys. 


\begin{abstract}
Household production constitutes an important aspect of economic activity and ignoring it may lead to incorrect inferences about levels and changes in well-being. This paper sheds light on the importance of unpaid work by making use of detailed time-use surveys for 26 OECD member countries and 3 emerging economies. The calculations suggest that between one-third and half of all valuable economic activity in the countries under consideration is not accounted for in the traditional measures of well-being, such as GDP per capita. In all countries, women do more of such work than men, although to some degree balanced - by an amount varying across countries - by the fact that they do less market work. While unpaid work - and especially the gender division of unpaid work - is to some extent related to a country's development level, country cross-sectional data suggest that demographic factors and public policies tend to exercise a much larger impact. The regular collection of time-use data can thus be of tremendous value for government agencies to monitor and design public policies, and give a more balanced view of wellbeing across different societies.
\end{abstract}

\title{
RÉSUMÉ
}

La production des ménages constitue un aspect important de l'activité économique et sa non prise en compte risquerait d'aboutir à des conclusions erronées concernant les niveaux de bien-être et leurs variations. Ce document met en lumière l'importance du travail non rémunéré en utilisant des enquêtes détaillées sur l'utilisation du temps dans 26 pays membres de l'OCDE et 3 économies émergentes. Les calculs montrent qu'une part comprise entre le tiers et la moitié de la totalité de l'activité économique utile dans les pays examinés n'est pas prise en compte dans les indicateurs traditionnels du bien-être tels que le PIB par tête. Dans tous les pays, les femmes effectuent davantage de travaux de cette nature que les hommes, bien que ce fait soit compensé dans une certaine mesure - dans des proportions qui varient selon les pays - par le fait qu'elles offrent moins de services marchands. Bien que les travaux non rémunérés - et plus particulièrement la répartition de ces travaux entre les deux sexes - soient liés dans une certaine mesure au niveau de développement, des données transversales portant sur les différents pays montrent que les facteurs démographiques et les politiques publiques ont en général une incidence beaucoup plus importante. La collecte périodique de données concernant l'utilisation du temps peut donc présenter un intérêt considérable pour les organismes publics en leur permettant d'assurer le suivi et la conception des politiques publiques et en donnant une image plus équilibrée du bien-être dans les différentes sociétés. 
TABLE OF CONTENTS

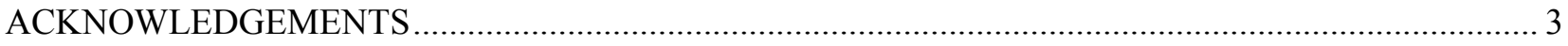

ABSTRACT …

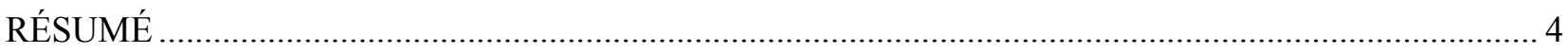

COOKING, CARING AND VOLUNTEERING: UNPAID WORK AROUND THE WORLD .................. 6

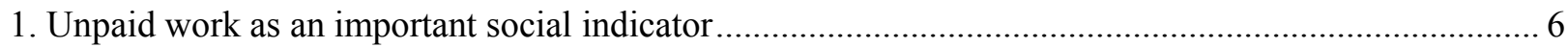

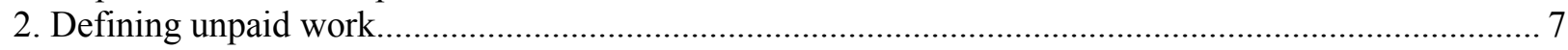

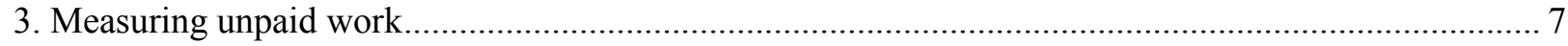

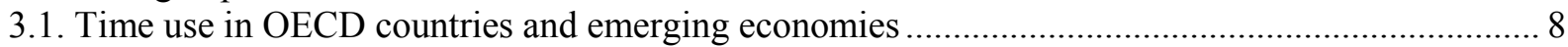

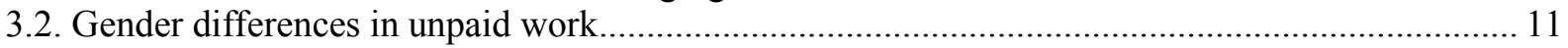

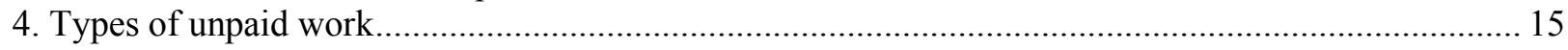

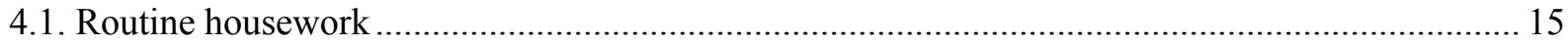

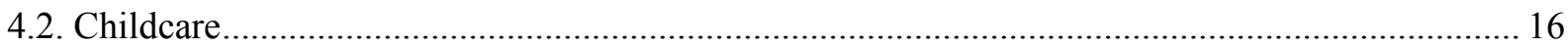

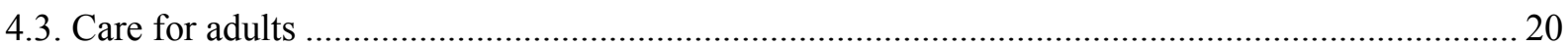

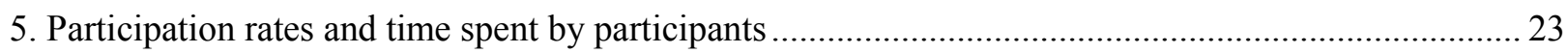

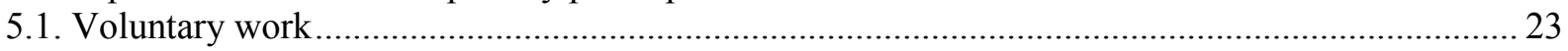

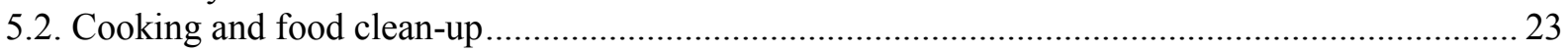

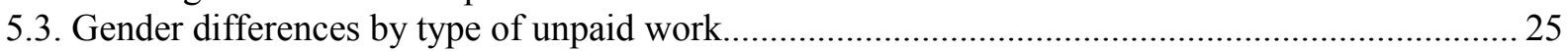

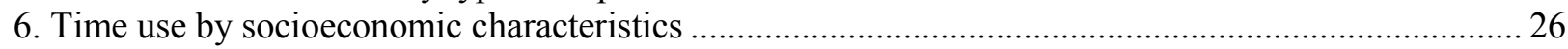

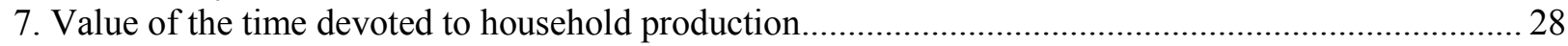

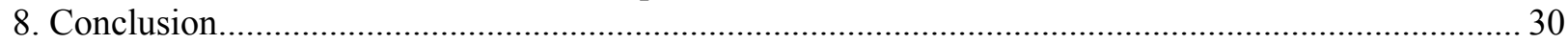

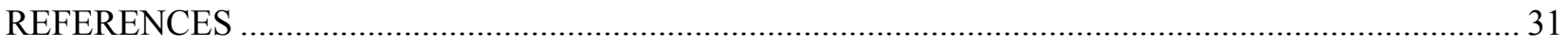

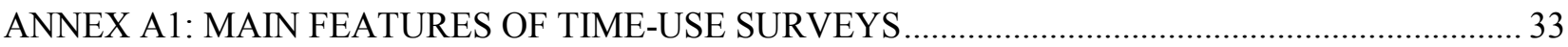

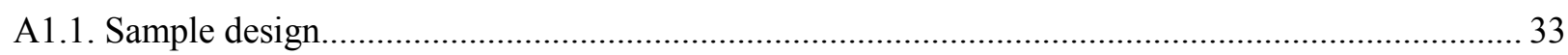

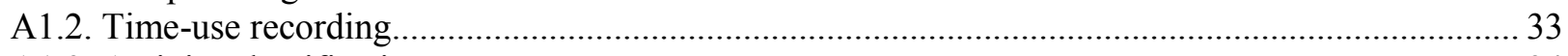

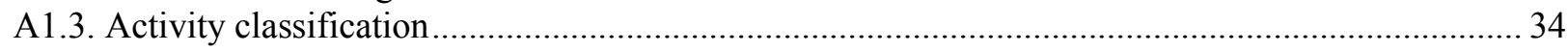

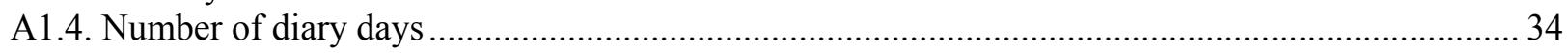

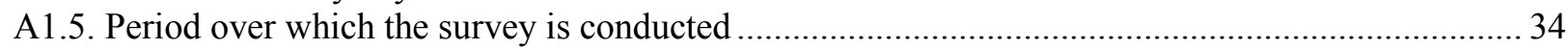

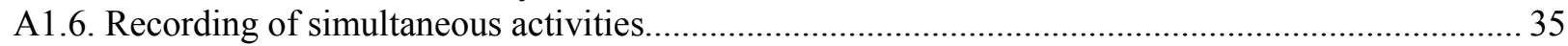




\section{COOKING, CARING AND VOLUNTEERING: UNPAID WORK AROUND THE WORLD}

\section{Unpaid work as an important social indicator}

1. At a national level, well-being is often proxied by aggregate income or production per head (e.g. GDP per capita) and changes in well-being by the corresponding rate of growth. However, neither measure is fully adequate if there is a considerable amount of unpaid work or if growth occurs because of substitution of paid for unpaid hours of work (Weinrobe, 2005). As argued by Stiglitz et al. (2009), household production constitutes an important aspect of economic activity. Ignoring it may lead to incorrect inferences about levels and changes in well-being. Since women traditionally do much of the unpaid work, so neglecting to include it underestimates women's contribution to the economy.

2. Families devote substantial unpaid time to productive activities such as cooking, cleaning and caring. This unpaid work increases overall consumption of goods and services and represents implicit income (Becker, 1965). As countries industrialise, a large part of the household production of food, clothing and caring for family members is transferred to the market and purchased by families. While this is a simple shift from the non-market to the market sector, it translates into a rise in income as measured by income and production aggregates and gives a false impression of an improvement in living standards.

3. Ignoring home production may also bias measures of income inequality and poverty rates (Abraham and Mackie, 2005). For instance, families where one parent has the time to do routine housework and take care of the children will have a higher disposable income than families with the same income, but where both partners work and external cleaning and childcare services are purchased. While standard measures of household living standards treat these two families as identical, Frazis and Stewart (2010) show that the extended income measure, which incorporates the value of household production, will be more equally distributed as unpaid work varies much less than paid work across households.

4. In addition to unpaid work within the household, people also carry out vital unremunerated work for relatives who live outside the household and for the wider community. Voluntary work, such as helping out neighbours, caring for older people or people with disabilities, supporting charities, assisting new immigrants, training sports teams, and administering schools, also contribute to societal well-being but are not included in the traditional economic measures.

5. This paper sheds light on the importance of unpaid work by making use of detailed time-use surveys for 26 OECD member countries and 3 OECD enhanced engagement countries (China, India and South Africa). ${ }^{1}$ These time-use surveys measure the time devoted to work, leisure and personal care by recording data on people's time allocation during the day.

6. After defining unpaid work in the following section, the amount of time devoted to both market and non-market work is measured and cross-national patterns of unpaid work are analysed. The data also

1. For the other countries, the time-use survey is either too old (Czech Republic, 1990, Greece, 1996, Israel, 1991, and Luxembourg, 1996), does not exist (Brazil - a new time-use survey is currently being undertaken - Iceland, Russia and Switzerland) or the sample is too small (Chile, Indonesia and Slovak Republic). 
make it possible to analyse distribution by gender and other socioeconomic characteristics. Special attention is devoted to the measurement of caring for household members, both children and adults. In the final section an estimation of the value of unpaid work is presented.

\section{Defining unpaid work}

7. Unpaid work is the production of goods and services by household members that are not sold on the market. Some unpaid work is for the consumption within the family, such as cooking, gardening and house cleaning. The products of unpaid work may also be consumed by people not living in the household, e.g. cooking a meal for visiting friends, helping in a soup kitchen for homeless people, mowing the lawn of an elderly relative, or coaching the local football team. ${ }^{2}$

8. The boundary between unpaid work and leisure is determined by the so-called "third-person" criterion. If a third person could hypothetically be paid to do the activity, it is considered to be work. Cooking, cleaning, child care, laundry, walking the dog and gardening are therefore all examples of unpaid work. On the other hand, someone else cannot be paid to watch a movie, play tennis, or silently read a book on another's behalf as the benefits of the activity would accrue to the doer (the third person), and not to the hirer (Ironmonger, 1996). These activities are therefore considered as leisure.

9. Some unpaid work, e.g. playing with children, walking the dog, cooking or tending a garden, is often enjoyable, depending on the state of mind and other time pressures (see Society at a Glance 2009 on reported enjoyment of various activities). The satisfaction from the activity is a benefit that cannot be transferred to another person. Similarly, many people derive a great deal of personal satisfaction from paid work and enjoy their time spent in their job. Thus the level of enjoyment of the person doing the activity cannot be used as a criterion to distinguish between work and leisure (Hill, 1979). ${ }^{3}$

\section{Measuring unpaid work}

10. To get a better idea of how much time people spend on unpaid work, detailed data on time use across the OECD countries are used. Up-to-date time-use surveys with sufficient information for this study are available for 26 OECD member countries and three OECD enhanced engagement countries (China, India and South Africa). Time-use surveys precisely record how people allocate their time over different activities, typically using a 24-hour diary. In addition, these surveys provide information on the context of the activity (e.g. where people did it, who they did it with and what other activities they did at the same time), the frequency of the activity, as well as the socioeconomic characteristics of the individual and the household.

11. Since methodologies and approaches vary slightly across countries, several issues may affect country comparability of time-use data, including the collection methodology, the length of diary time

2. Unpaid work in a family business or farm, along with other forms of unremunerated employment picked up in standard labour force surveys is not considered as unpaid work in this paper and included under paid work instead. Also unpaid overtime work and the work that people take home without a formal payment arrangement are regarded as part of paid work.

3. Most countries use the third person criterion in their time-use surveys to define unpaid work, with the exception of Japan. For several activities, Japan makes a distinction between what is done as part of housework and what is done as leisure, e.g. "making sweet" vs. "making sweet as hobbies"; "making clothing" vs. "making clothing as hobbies"; and "gardening" vs. "gardening as hobby". Also "pet care" and "walking the dog" are both considered leisure. To maintain consistency with all other countries, we categorize what the Japanese Statistics Bureau calls "productive hobbies" under unpaid work, i.e. "gardening as hobbies", "making sweet as hobbies", "making clothing", "pet care", and "walking the dog". 
slots, and the number of days on which diaries are completed. All issues are discussed in detail in Annex A1, but three of them require special attention and should be kept in mind when interpreting the results presented in this paper. Ideally, time-use surveys are spread over the whole year and thus contain a representative proportion of weekdays and weekend days, as well as public and school holidays. Some countries, however, only cover particular periods in the week or year, which are typically chosen to avoid seasonal biases such as those due to public holidays or annual leave for workers. This is the case, to varying degrees, for Canada, China, Denmark, France, Ireland, Japan, Korea, Mexico and South Africa. The exclusion of holiday periods may lead to a slight overestimation of annual paid working time and underestimation of unpaid work and leisure time (see Table A1.1 in Appendix A1). Since the results in this paper are represented as time use on an average day of the year, the exclusion of holiday periods might slightly bias the figures of these nine countries. Second, Ireland and Mexico use a simplified variant of the time-use diary, as opposed to the other countries where respondents keep a 24-hour diary during one or more days in which they precisely record each activity. As a result, the time-use estimates for Ireland and Mexico are much less precise than for other countries. In addition, in the Mexican time-use survey, respondents are asked about their time use during the seven days prior to the interview. Given the large time lapse between the activity and the interview, responses are likely to be rougher estimates of the true time use. Third, as time-use surveys were taken in different years, with countries at different stages in the economic cycle and with access to different levels of technology, this may be another reason for observed between-country variations.

12. To improve the comparison of time use across countries, the samples are restricted to populations aged 15-64 and activities are aggregated into five main categories: (1) Unpaid work; (2) Paid work or study; (3) Personal care; (4) Leisure; and (5) Other time use. "Unpaid work" includes activities like routine household work (e.g. cooking, cleaning, and gardening), caring for children and other family and nonfamily members, volunteering, and shopping. "Paid work or study" covers full-time and part-time jobs, unpaid work in family business/farm, breaks in the workplace, time spent looking for work, time spent in education, and homework. "Personal care" covers sleep, eating and drinking, and other household, medical, and personal services (hygiene, grooming, visits to the doctor, etc.). "Leisure" includes hobbies, watching television, computer use, sports, socialising with friends and family, attending cultural events, and so on. "Other" contains religious activities and civic obligations, as well as unspecified time use. For each of the categories only primary activities are taken into account, while simultaneous or secondary activities are excluded to improve comparability across countries (see Appendix A1 for discussion).

13. Time spent on travel is treated as a derived activity and classified in the same category as the activity to which it is linked, even though, strictly speaking, travelling does not follow the third-person criterion of unpaid work, as it is not possible to hire someone to travel on one's behalf. Journeys can, however, also have multiple destinations. Often people try to save time by combining travel to work with dropping off their children at school or shopping on the way home. As a rule, travelling time is recorded in the time-use surveys according to the destination. For example, driving from home to work is regarded as travel related to paid work, from work to school as travel related to childcare, from school to the grocery store as travel related to shopping, and from the grocery store to home as travel related to shopping.

\subsection{Time use in $\mathrm{OECD}$ countries and emerging economies}

14. Across the 29 countries for which data are available (all OECD averages used in this paper are unweighted averages of the countries presented in the charts), people average 3.4 hours per 24-hour day on unpaid work, the equivalent of $14 \%$ of their total time (Figure 1). The variation in unpaid working time across countries is great. With 4.2 hours per day Mexicans spend the most time on unpaid work, while people in Japan, Korea and China do the least unpaid work (only 2.4-2.7 hours per day). In all countries, personal care, including sleeping and eating, takes up most of people's time, accounting for $46 \%$ of a $24-$ hour day on average. The remaining time is spent on leisure (20\% of people's total time) and in 
employment or study (on average $19 \%$ of people's time). Less than $1 \%$ of a day is devoted on average to religious activities and other unspecified time use.

\section{Figure 1. People spend one-tenth to one-fifth of their time on unpaid work}

Time use by main activity in percentage of total time use for the population aged 15-64 over the period 1998-2009 ${ }^{1}$

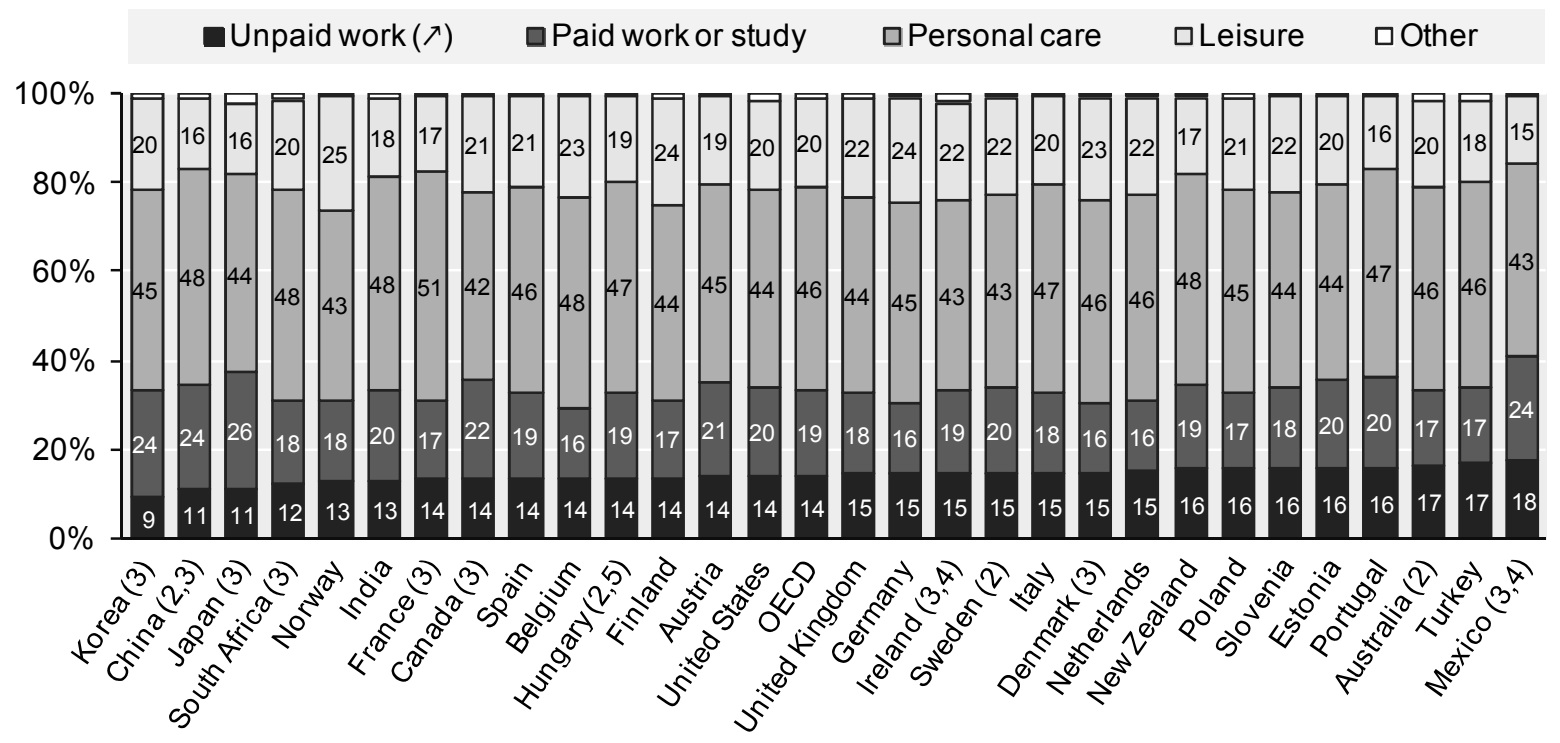

(1) The years covered are: Australia: 2006; Austria: 2008-09; Belgium: 2005; Canada: 2005; China: 2008; Denmark: 2001; Estonia: 1999-2000; Finland: 1999-2000; France: 1998-99; Germany: 2001-02; Hungary: 1999-2000; India: 1999; Italy: 2002-03; Ireland: 2005; Japan: 2006; Korea: 2009; Mexico: 2009; Netherlands: 2006; New Zealand: 1998-99; Norway: 2000-01; Poland: 2003-04; Portugal: 1999; Slovenia: 2000-01; South Africa: 2000; Spain: 2002-03; Sweden: 2000-01; Turkey: 2006; United Kingdom: 2000-01; and United States: 2008.

(2) For a number of countries it was not possible to restrict the sample to the population aged 15-64. Instead, the age limits are: Australia: 15+; China: 15-74; and Hungary: 15-74; Sweden: 20-64. A different upper age limit is unlikely to affect the time use significantly. A lower age limit, on the other hand, is likely to diminish the importance of unpaid work. See section 6.1 for a discussion.

(3) Surveys for Canada, China, Denmark, France, Ireland, Japan, Korea, Mexico and South Africa do not cover a complete calendar year and may thus, to varying degrees, under-represent holiday periods. As people do more unpaid work on weekends, the exclusion of holidays is likely to lead to an overestimation of paid working time and an underestimation of unpaid work and leisure time (see Annex A1.5).

(4) Ireland and Mexico use a simplified variant of the time-use diary, as opposed to the other countries where respondents keep a 24hour diary during one or more days in which they precisely record each activity. In addition, Mexicans are asked about their time use during the seven days prior to the interview. Hence, the estimates for Ireland and Mexico are much less precise than for the other countries (see Annex A1.2).

(5) For Hungary, only pre-prepared tables on time use are available and the categories are not always entirely comparable with the aggregations used for the other countries. The comparison of Hungary with the other countries should thus be interpreted with caution.

Source: Secretariat estimates based on national time-use surveys (see Table A1.2 for more details).

15. Be it paid or unpaid, people spend about one-third of their time working. The total working time - the sum of paid and unpaid work, including travelling time - is lowest in West-Europe and South Africa and highest in Japan and Mexico (Figure 2). In the latter two countries, people work respectively 9 and 10 hours per day in total, while people in Belgium, Denmark, Germany, and South Africa work on average about 7.1-7.4 hours per day. In most countries, time spent on paid work exceeds time spent on unpaid work (with the exceptions of Australia and Turkey), with the averages being 4.6 hours for paid work and 3.5 hours for unpaid work. While the average daily paid working time seems low at first sight, it should be 
borne in mind that these figures cover weekdays and weekend days, as well as holiday periods, and include both employed and non-employed individuals.

Figure 2. Total working time is lowest in West-Europe and highest outside Europe

Total minutes worked, paid and unpaid, per day for the population aged 15-64 over the period 1998-2009 ${ }^{1}$

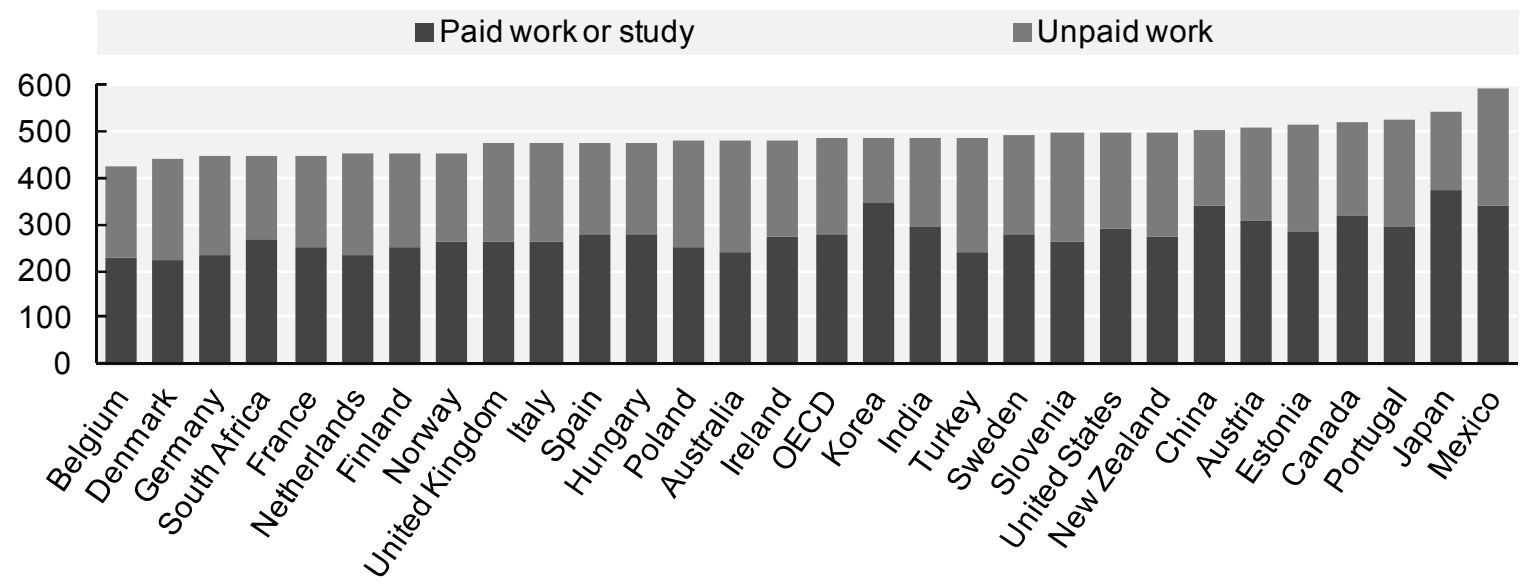

(1) Travelling time related to paid and unpaid work is included in the respective categories. See Figure 1 for country-specific notes.

Source: Secretariat estimates based on national time-use surveys (see Table A1.2 for more details).

16. Plotting the paid working time against the unpaid working time shows that there is a negative relation between paid and unpaid work (Figure 3). Countries with high average paid working time (China, Japan and Korea) tend to have low average unpaid working time, while the opposite is true for Western Europe, Australia, and Turkey. The apparent trade-off between unpaid and paid work is also reflected in the lower variation for total working time across countries (coefficient of variation of 0.07) compared with that of paid work and unpaid work separately, which have a coefficient of variation of 0.14 and 0.12 respectively. 
Figure 3. Trade-off between paid and unpaid work

Minutes of paid and unpaid work for the population aged 15-64 over the period 1998-2009 ${ }^{1}$

Minutes of unpaid work per day

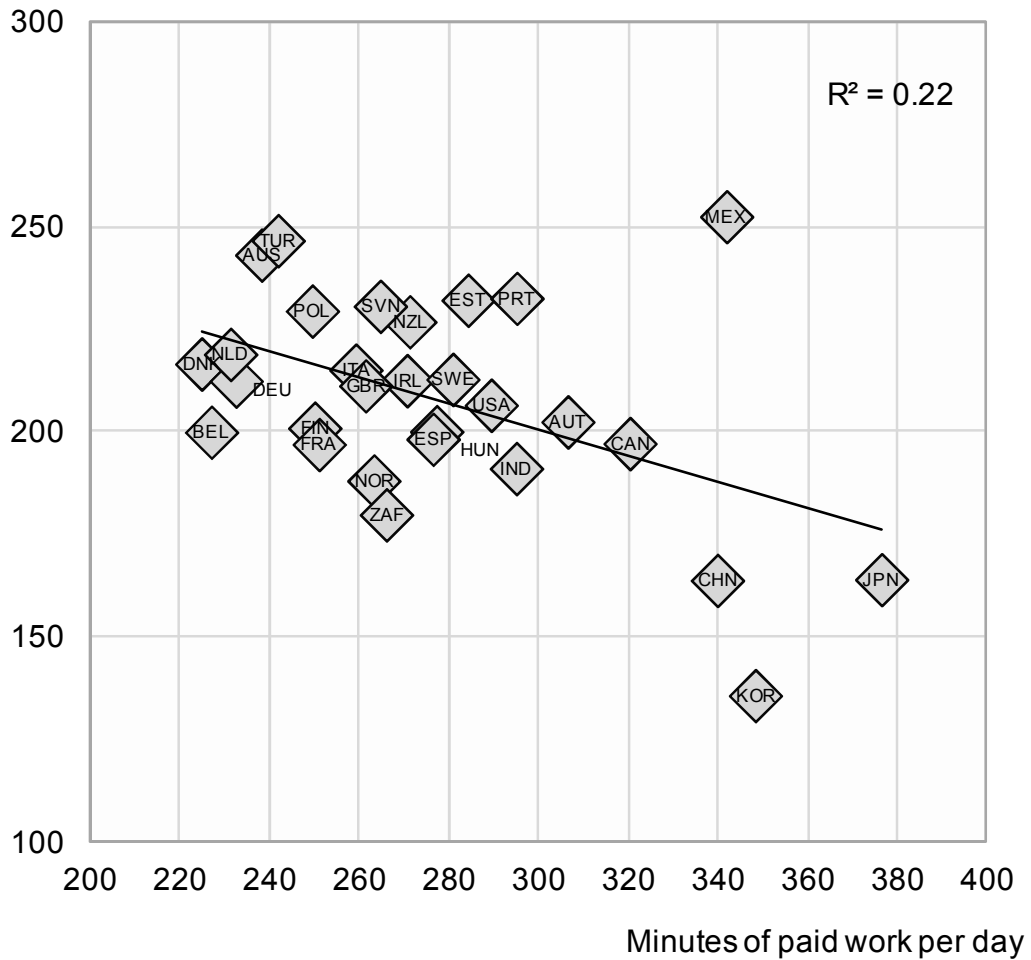

(1) Travelling time related to paid and unpaid work is included in the respective categories. See Figure 1 for country-specific notes.

Source: Secretariat estimates based on national time-use surveys (see Table A1.2 for more details).

\subsection{Gender differences in unpaid work}

17. In each of the countries under consideration, women spend more time on unpaid work than men (Figure 4). The gender gap is on average 2 hours and 28 minutes per 24-hours day, but there is significant divergence across countries. For instance, Turkish, Mexican and Indian women spend per day 4.3-5 hours more on unpaid work than men in those countries, while the difference is only a little over one hour per day in the Nordic countries. The Indian and Mexican gender differences are mainly driven by the long hours Indian and Mexican women spend in the kitchen and caring for the children while men are at work. Indian men also spend considerably more time sleeping, eating, talking to friends, watching TV and relaxing. Also in Southern Europe, Korea and Japan, women allocate much more time on unpaid work than their male compatriots.

18. Countries with the largest gender gap in unpaid work are also those countries where men devote relatively little time to unpaid work (Figure 5, Panel A). Men's unpaid working time averages less than 1 hour per day in the three Asian countries Korea, India and Japan, 1.5 hours in China and South Africa, nearly 2 hours in Turkey and the four Latin countries (Italy, Mexico, Portugal and Spain), and 2.5 hours in the rest of the countries shown here. Yet, the low amount of men's unpaid work is not always compensated by high amounts for women (Figure 5, Panel B). In China, for instance, both men and women spend very little time on unpaid work in comparison with other countries. In Australia, on the other hand, both sexes are at the top of the ranking. Overall, the female population in the OECD countries and emerging 
economies devotes on average 4.7 hours to unpaid work, which is 2.5 hours more than their male counterparts on average.

Figure 4. Women do more unpaid work than men in all countries

Female less male unpaid working time in minutes per day, for the population aged 15-64 over the period 1998-2009 ${ }^{1}$

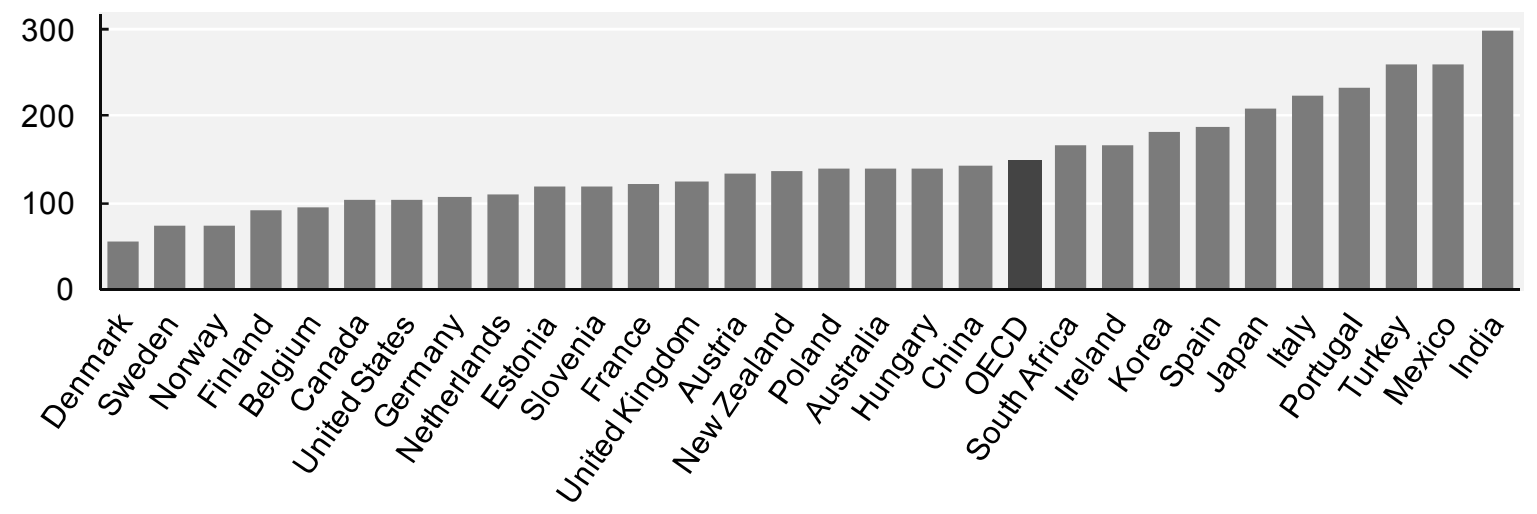

(1) See Figure 1 for country-specific notes.

Source: Secretariat estimates based on national time-use surveys (see Table A1.2 for more details). 
Figure 5. Asian men spend the least hours in unpaid work, Mexican and Turkish women the most

Minutes of unpaid work per day for the population aged 15-64 over the period 1998-2009 1

PanelA: Men

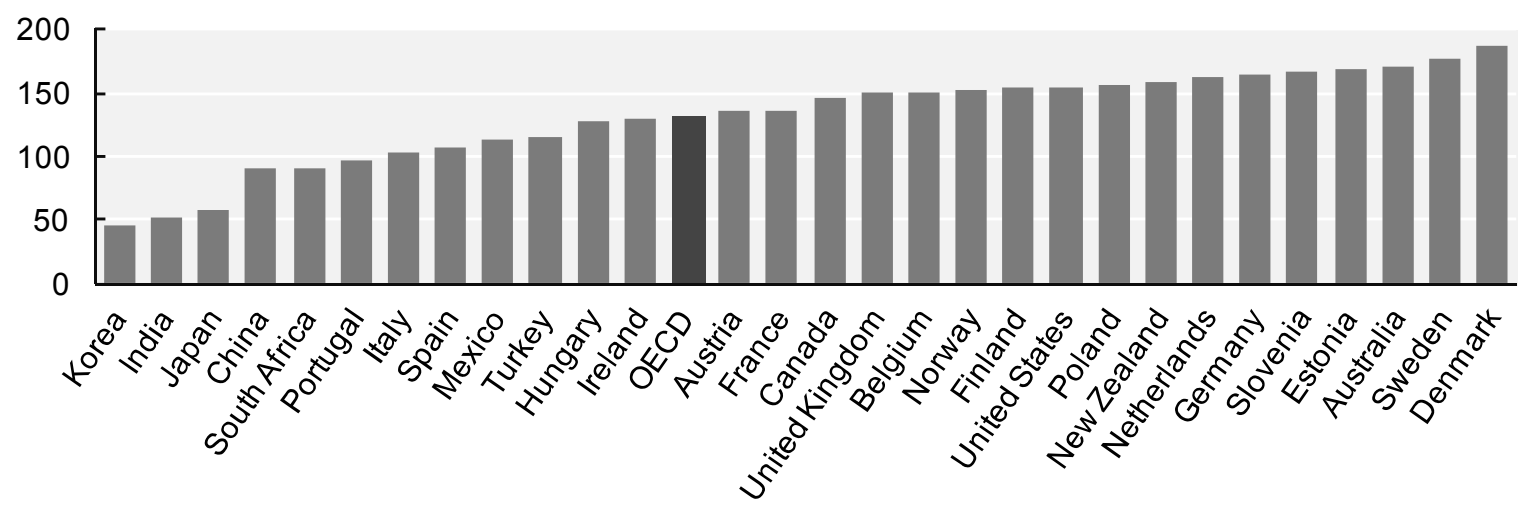

PanelB: Women

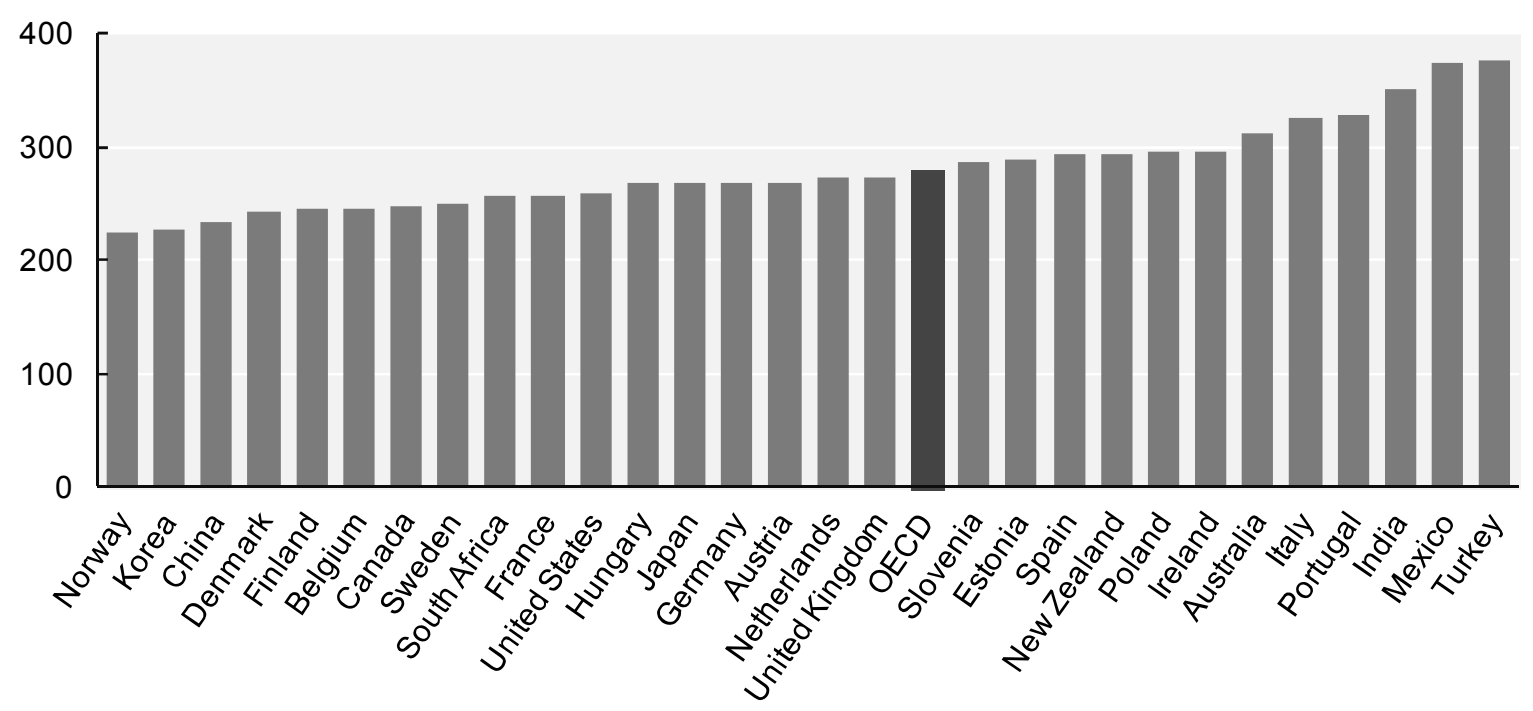

(1) See Figure 1 for country-specific notes.

Source: Secretariat estimates based on national time-use surveys (see Table A1.2 for more details).

19. What is driving these large gender differences in unpaid work? The time men and women devote to unpaid work is to some extent related to the level of economic development, although the correlations are rather weak: women's unpaid working time is negatively correlated with GDP per capita (coefficient of -0.37), while that of men is positively correlated with GDP per capita (coefficient of 0.36). As argued by Folbre (2009), the level of development probably exercises less impact on unpaid working time than demographic factors and public policies.

20. While women have traditionally been responsible for housework and caring, they have become increasingly active in the paid labour market over the past few decades and have decreased their unpaid working time (Freeman and Schettkat, 2005). From a cross-country perspective, there is a strong negative correlation between a country's female employment rate and women's average unpaid working time (Figure 6). Part of the slack in unpaid working time is taken up by men, as shown by the positive 
correlation between a country's female employment rate and men's average unpaid working time. Yet, even in the country with the highest average unpaid working time among men - Denmark - men still devote less time to unpaid work than women in Norway, the country with the lowest female unpaid working time.

Figure 6. Men's unpaid work increases with national levels of women's employment, while women's unpaid work decreases ${ }^{1}$

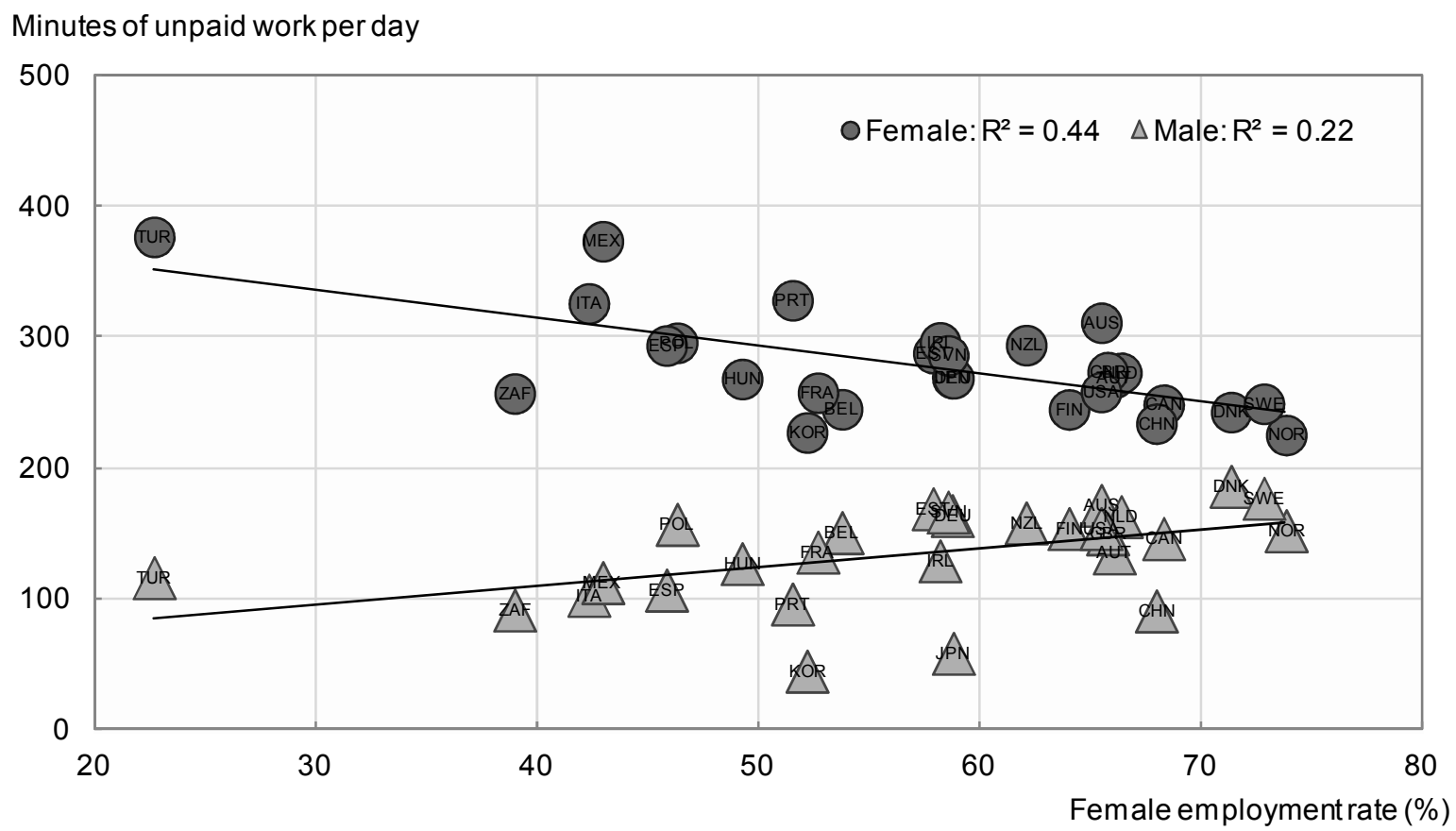

(1) Time use for the population aged 15-64 over the period 1998-2009. The female employment rates are for the population aged 1564 years and correspond to the year during which the time-use survey was undertaken. See Figure 1 for country-specific notes.

Source: Secretariat estimates based on national time-use surveys (see Table A1.2 for more details) and OECD Labour Force Surveys for female employment rates.

21. Part of the reason for women's higher share of unpaid work is their shorter time in paid work. As shown in Figure 7, the gender difference in total working time - the sum of paid and unpaid work, including travelling time - is close to or below zero for countries with relatively high female employment. That means that the longer hours spent on housework and caring by women are compensated with shorter hours in paid work. Part-time paid work for women is common in Australia, Germany, Japan, the Netherlands, and the United Kingdom, where more than $40 \%$ of women work on a part-time basis (OECD, 2007). In countries with a relative lack of opportunity for part-time work, particularly in Southern Europe, the presence of children is an important factor associated with women's exit from the labour market (Lewis et al., 2008). These countries are also those were women work much longer hours in total (Figure 7).

22. Recent studies suggest that government policies, such as working-time regulations, family policies and gender equality initiatives, can influence women's role as caregiver and therefore counter the egalitarian trend in the division of housework (Baker, 1997; Gornick and Meyers, 2003; and Hook, 2006). On the one hand, publicly subsidized formal childcare relieves mothers of some child-care responsibilities and encourages their labour force participation. On the other hand, long parental leave arrangements continue to be primarily used by women - mothers are often reluctant to give up leave to their partner's benefit - reinforcing traditional gender roles and damaging mothers' labour attachment. Non-transferable paternal entitlement to paid leave increase chances of more equal leave sharing between mothers and 
fathers, but so far there is no evidence of the longer-term effect on the division of housework (OECD, 2011a).

Figure 7. Countries with high female paid employment have a more equal gender division in total working time ${ }^{1}$

Female-male gender gap in total working time, minutes per day

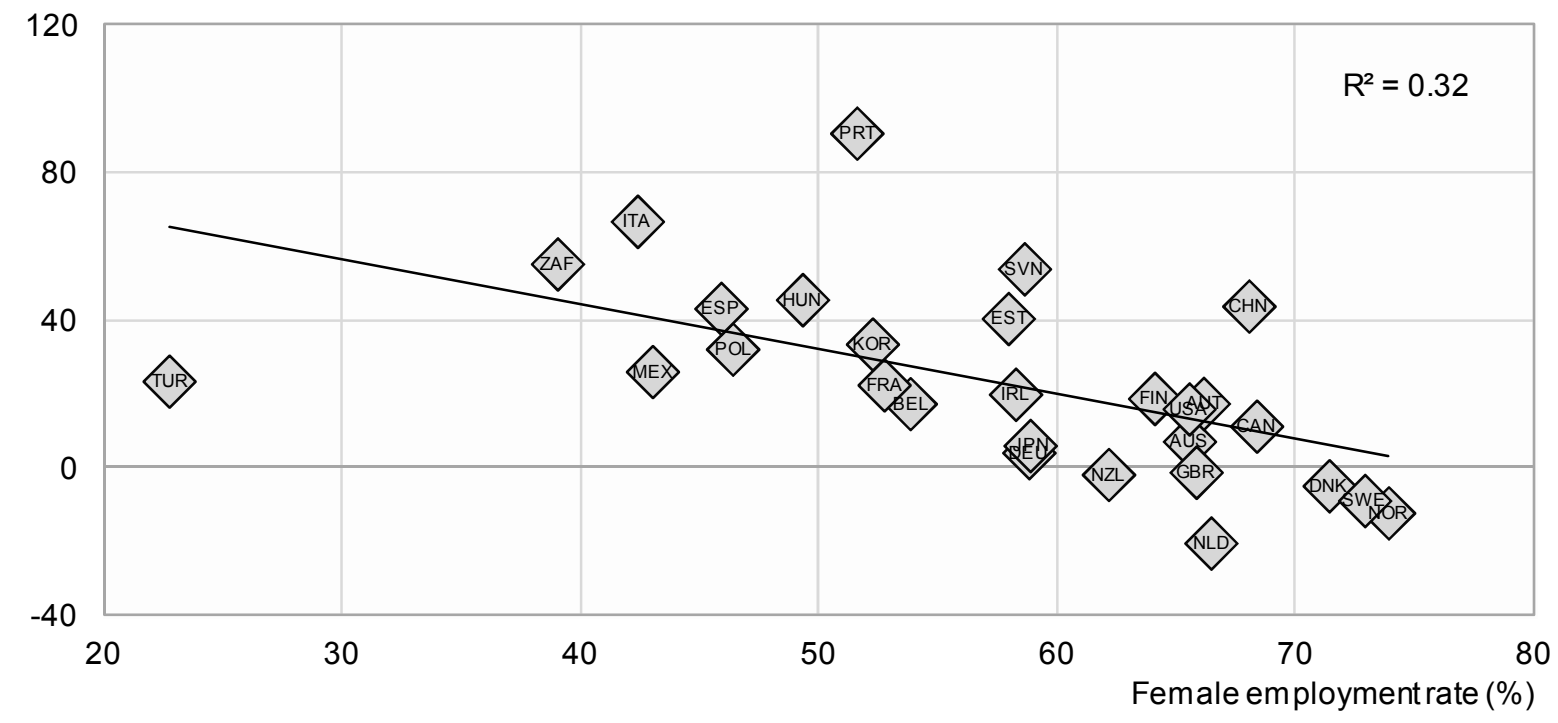

(1) Time use for the population aged 15-64 over the period 1998-2009. The female employment rates correspond to the year during which the time-use survey was undertaken. See Figure 1 for country-specific notes.

Source: Secretariat estimates based on national time-use surveys (see Table A1.2 for more details) and OECD Labour Force Surveys for female employment rates.

\section{Types of unpaid work}

\subsection{Routine housework}

23. In all countries the main component of unpaid work is routine housework. Routine housework includes tasks as cooking, cleaning, gardening, pet care and home maintenance. Across 29 countries under consideration, people spend on average 2 hours and 8 minutes per day on routine housework (Figure 8). The total duration varies, however, greatly across countries, as does the importance of routine housework within total unpaid work. For instance, Koreans spend only 1.4 hours per day on routine housework, but it accounts for $60 \%$ of their total time spent on unpaid work. Australians, on the other hand, devote on average more than 2 hours to routine housework but it represents only half of their total unpaid working time. Compared with the other components of unpaid work, there is less variation across countries in routine housework (coefficient of variation of 0.17 ).

24. Care for household members and shopping are typically the next largest unpaid work categories, lasting respectively 26 and 23 minutes per day on average. The relative importance of both time categories differs across countries, but there is less variation in shopping (coefficient of variation of 0.26 ) than in caring (coefficient of variation of 0.34). The variation across countries is largest for voluntary work (coefficient of variation of 1.10), with the average daily volunteering time ranging from less than 1 minute in India and Korea to 13 minutes in New Zealand. 
Figure 8. Routine housework is the largest component of unpaid work

Minutes of unpaid work per day by main categories for the population aged 15-64 over the period 1998-2009 ${ }^{1}$

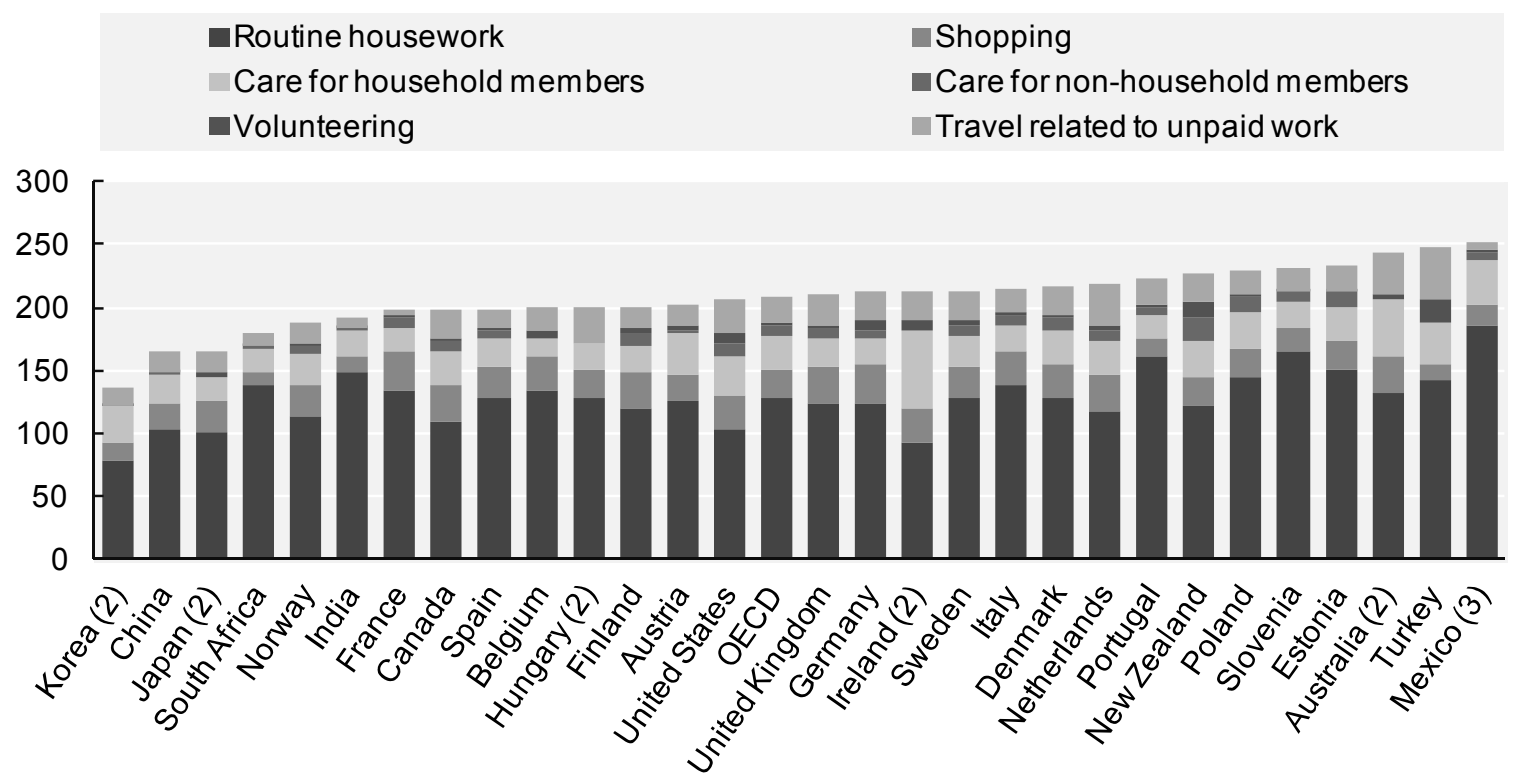

(1) See Figure 1 for additional country-specific notes.

(2) For Australia, Hungary and Ireland, care for household members cannot be separated from care for non-household members. In the Korean and Japanese time-use surveys, there is no distinction between care for household members and care for non-household members. Instead they make a distinction between family care and care for others. All care for family members is consequently included in the category care for household members, irrespective of whether the family members live in the household.

(3) For Mexico, travelling time cannot be separated from the activity to which it is linked, except for some travel related to child care. Each of the sub-categories is thus slightly overestimated.

Source: Secretariat estimates based on national time-use surveys (see Table A1.2 for more details).

\subsection{Childcare}

25. Caring, and in particular childcare, is one of the most difficult tasks on which to collect information. Unlike most other activities, care is often passive and combined with other activities, e.g. cooking while a child is playing in another room or watching television together with children. Time-use surveys try to deal with multitasking by recording both "primary" activities ("what were you doing?") and "secondary" activities ("were you doing anything else at the same time?"). One limitation of such respondent-recorded data collection is that primary activities tend to be meticulously tracked while secondary ones are usually overlooked (and in some countries not even collected). Some surveys encourage respondents to report their secondary activities by listing clear examples on the diary form. However, as not all countries prime respondents, the recording of secondary activities may vary significantly across countries (Folbre and Yoon, 2007).

26. Several surveys try to capture the diffuse nature of childcare by including additional childcare questions. These questions are defined either as the time spent in the proximity of a child (e.g. "who was with you?") or as the time being responsible for a child (e.g. "was a child in your care?" or "were you looking after a child?"). The advantage of such questions is that they are more likely to pick up respondents who would otherwise not record their responsibility. They also better capture passive childcare, which is fundamentally different from active childcare as it merely constrains other activities rather than being an activity in itself (Budig and Folbre, 2004). On the other hand, both the proximity 
method and the responsibility method may overstate childcare when several adults share the caring responsibility for the child.

27. Figure 9 sets out the different methodologies of measuring childcare: the respondent-recorded method in Panel A and the proximity and responsibility method in Panel B. Across the 22 countries for which consistent data are available, ${ }^{4}$ parents devote on average 1 hour and 12 minutes per day to childcare as a primary activity. Adding secondary childcare raises the average substantially to almost 2 hours per day. ${ }^{5}$ Total time devoted to (primary) childcare is lowest in Korea, Belgium and Hungary - occupying less than one hour per day - and highest in the Anglophone countries. The impact of encouraging respondents to report secondary childcare is visible in the extremely high childcare estimates for Australia. In the instructions of the Australian time diary there are clear examples of secondary childcare which encourage parents to record passive childcare. The largest category of secondary childcare in Australia is child minding, accounting for almost 4 hours per day for parents of children under 15 years of age.

28. In Panel B of Figure 9, the two measures of passive childcare are compared. In the 16 countries which added a proximity question to their time-use survey, parents spend on average 4.1 hours per day with their children. The responsibility method (asked only in two countries) provides even higher estimates of childcare, reaching 6.7 hours per day in the United States and 5.3 hours in Canada, although the difference with the proximity method is minimal for Canada. The country ranking of passive childcare is very similar to the active childcare measures in Panel A, with Slovenia and Belgium at the bottom and Austria, Denmark and Ireland at the top.

Figure 9. Parents' active and passive childcare

Minutes of childcare per day for the population aged 15-64 over the period 1998-2009

Panel A: Respondent-recorded childcare ${ }^{2}$

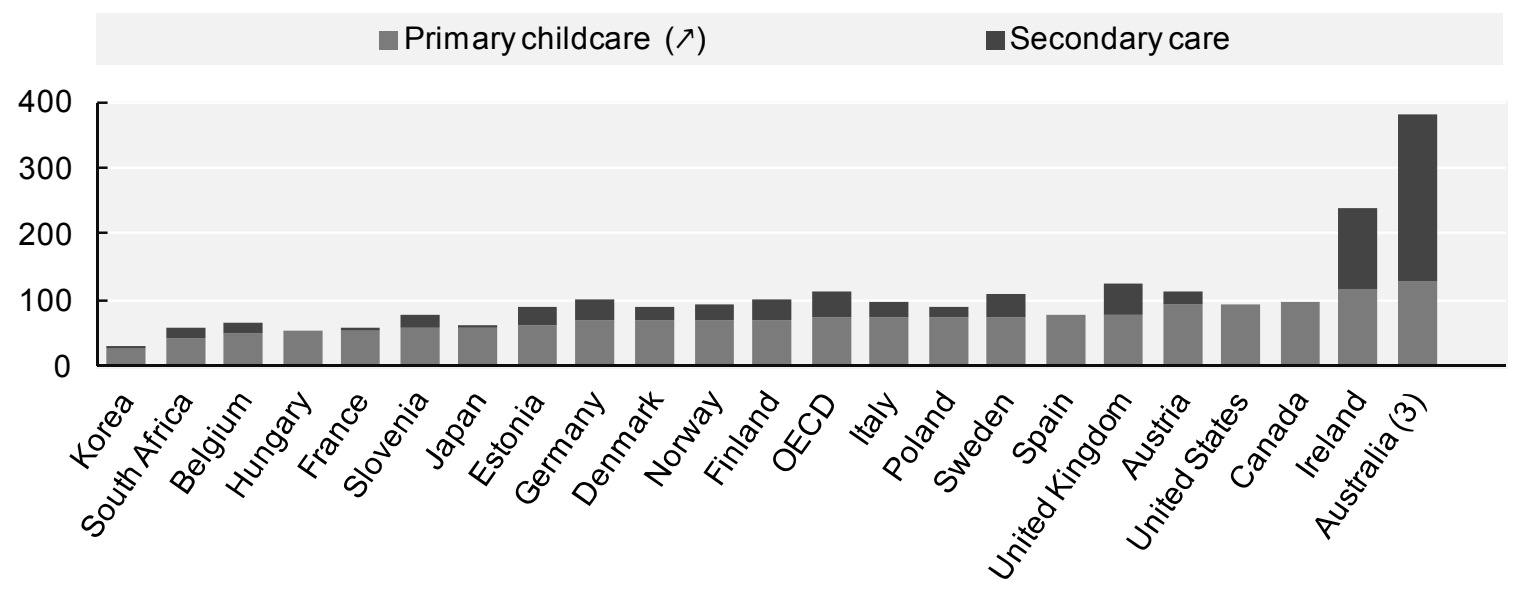

4. There are no data on parents' childcare activities for China, India, Mexico, the Netherlands, New Zealand and Turkey. For Portugal, there is only information on the proximity measure of parents' childcare.

5. Time-use surveys in Canada, Hungary and the United States do not ask about secondary activities. For Spain, estimates on secondary childcare are not available. 
Panel B: Proximity and responsibility method ${ }^{4}$

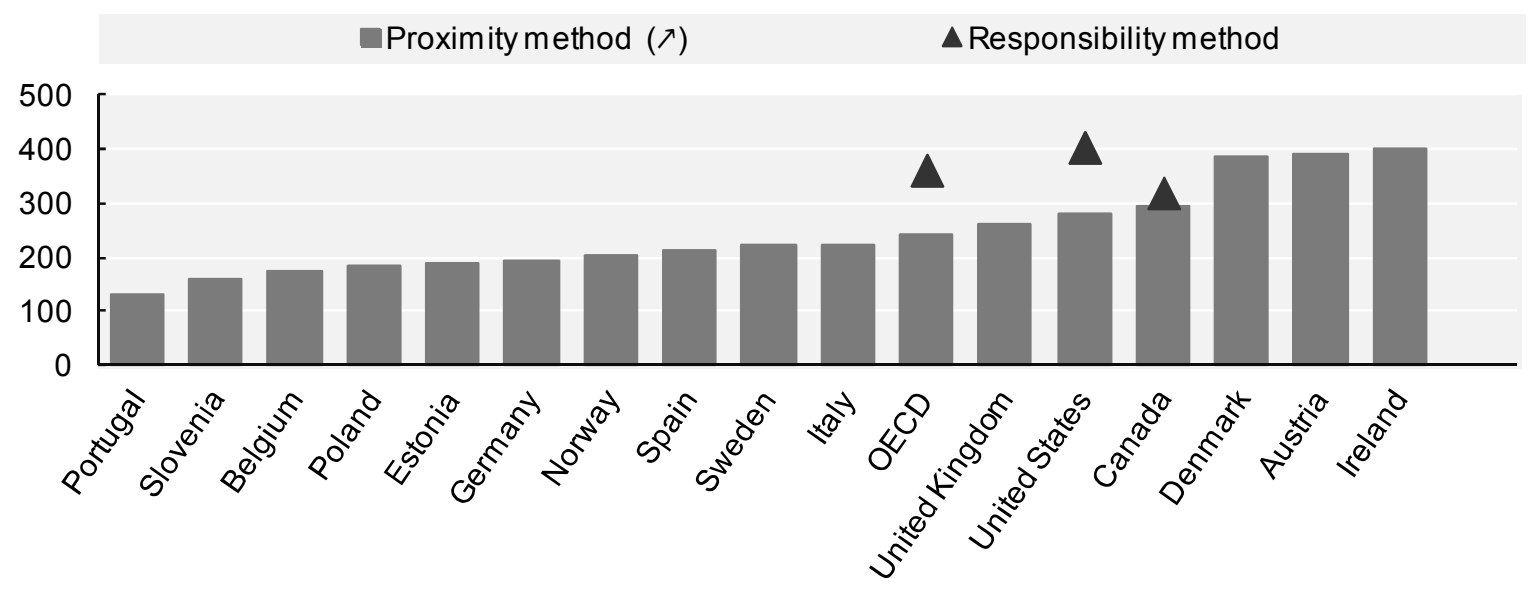

(1) See Figure 1 and Figure 8 for additional country-specific notes.

(2) Respondent-recorded childcare refers to the amount of time spent on childcare that respondents report themselves in their timeuse diaries, either as a primary or secondary activity. The estimates refer to care for children under the age of 18, except for Australia and Canada (less than 15 years).

(3) The estimates for Australia also include the time spent on care of non-household children. However, this is unlikely to affect the results significantly as care for non-household children tends to be negligible compared with care for household children. For instance, in the United States, parents devote on average 77 minutes per day to care for children of their own household, compared with 2 minutes for non-household children.

(4) The proximity method measures passive childcare by the amount of time spent in the presence of a child. The responsibility method measures passive childcare based on the amount of time respondents are responsible for the care of a child. Unfortunately, the age cut-off for both methods differs significantly across countries: 10 years in most European countries - with the exception of Denmark (18 years), Ireland (18 years), and Portugal (14 years) - 15 years in Canada and 13 years in the United States.

Source: Secretariat estimates based on national time-use surveys (see Table A1.2 for more details).

29. The labour force status is an important determinant of the time parents devote to childcare. Both fathers and mothers who are not working spend on average more time in childcare as primary activity than their working counterparts (Table 1). Yet, while non-working fathers increase their caring time by only 11 minutes per day from 40 to 51 minutes per day, mothers who do not work double their caring time from 74 to 144 minutes per day. The difference in caring time by labour status reaches almost 2 hours for mothers in Estonia, Finland, Germany and Norway, while the gap for fathers is particularly small in Finland, Korea and Sweden, becoming even slightly negative for Denmark, South Africa and Slovenia - i.e. non-working fathers do less childcare than working fathers. The fact that non-working fathers still devote less time to childcare than working mothers in nearly all surveyed countries (except in Hungary and the United States) confirms the traditional gender division of labour discussed in Section 3.2.

30. The empirical literature on parental caring time has shown that also the age of the youngest child and parents' education are particularly important determinants of the time parents devote to childcare. While the extra caring time associated with an additional child is limited, primary childcare time rapidly declines as the age of the youngest child increases. The effect of the child's age on supervisory time is much more limited (Folbre and Yoon, 2007). In addition, better educated parents tend to devote significantly more time to primary childcare and provide a richer variety of caring activities to their children than less educated parents (Sayer, Gauthier and Furstenberg, 2004, and Guryan, Hurst and Kearney, 2008). The fact that the amount of time allocated to home production and leisure falls as education and income rise, illustrates that highly-educated parents tend to compensate for time away from children in employment by prioritizing childcare over leisure and sleeping. This, in turn, suggests that better educated parents view child care as an investment in their children's future. 
DELSA/ELSA/WD/SEM(2011)1

Table 1. Non-working fathers devote less time to childcare than working mothers in nearly all countries

Primary childcare in minutes per day for the population aged 15-64 over the period 1998-2009 ${ }^{1}$

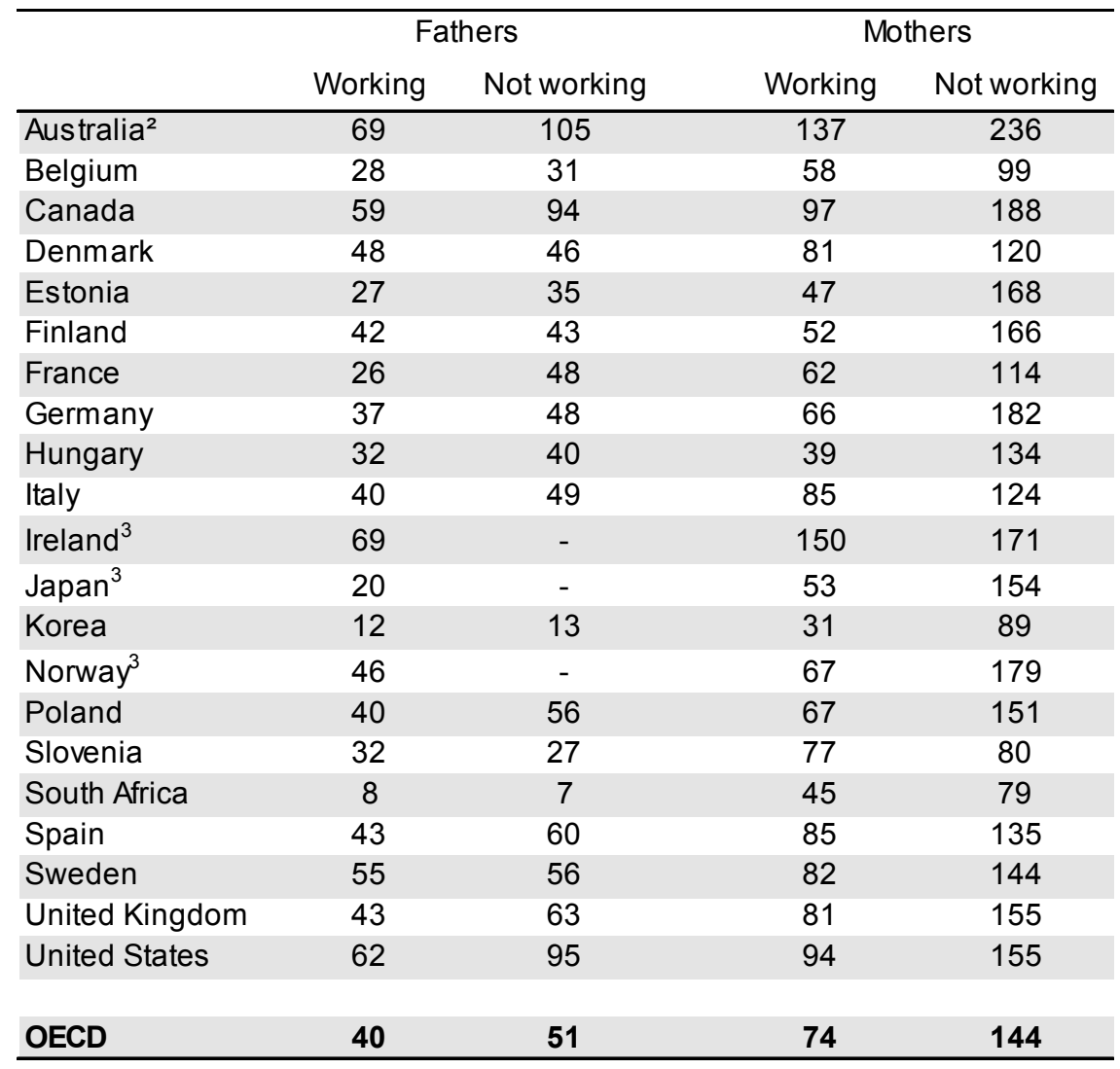

(1) The estimates refer to care for children under the age of 18, except for Australia and Canada (less than 15 years). Working parents included both full-time and part-time workers. Non-working parents includes parents on leave, and unemployed, inactive and retired parents. See Figure 1 and Figure 8 for country-specific notes.

(2) The estimates for Australia include the time spent on care of non-household children.

(3) The sample of non-working fathers is too small in Ireland, Japan and Norway.

Source: Secretariat estimates based on national time-use surveys (see Table A1.2 for more details).

31. Not only does the total amount of time devoted to childcare differ by parental gender, but so too does the kind of childcare activities. A distinction can be made between (1) physical care, such as meeting the basic needs of children, including dressing and feeding children, changing diapers, providing medical care for children, and supervising children; (2) educational and recreational childcare, such as helping children with their homework, reading to children, and playing games with children; and (3) travel related to any of the two other categories, e.g. driving a child to school, to a doctor or to sport activities. Mother's childcare time is dominated by physical childcare and supervision, accounting for $60 \%$ of their child-caring activities (Figure 10). Fathers, on the other hand, spend proportionally more time in educational and recreational activities than mothers, i.e. $41 \%$ of their total childcare time compared with $27 \%$ of mothers' total childcare time. Still, mothers spend more than twice as much time in childcare than do fathers, a pattern which holds for all countries and the different subgroups. In the 22 countries for which data are available, childcare takes up 42 minutes per day for fathers whereas it occupies 1 hour and 40 minutes of mothers' time. 
Figure 10. Women devote most of their time to physical childcare, while men devote most of their time to teaching, reading and playing with their children

Time devoted to different types of primary childcare for the population aged 15-64 over the period 1998-2009, OECD average 1

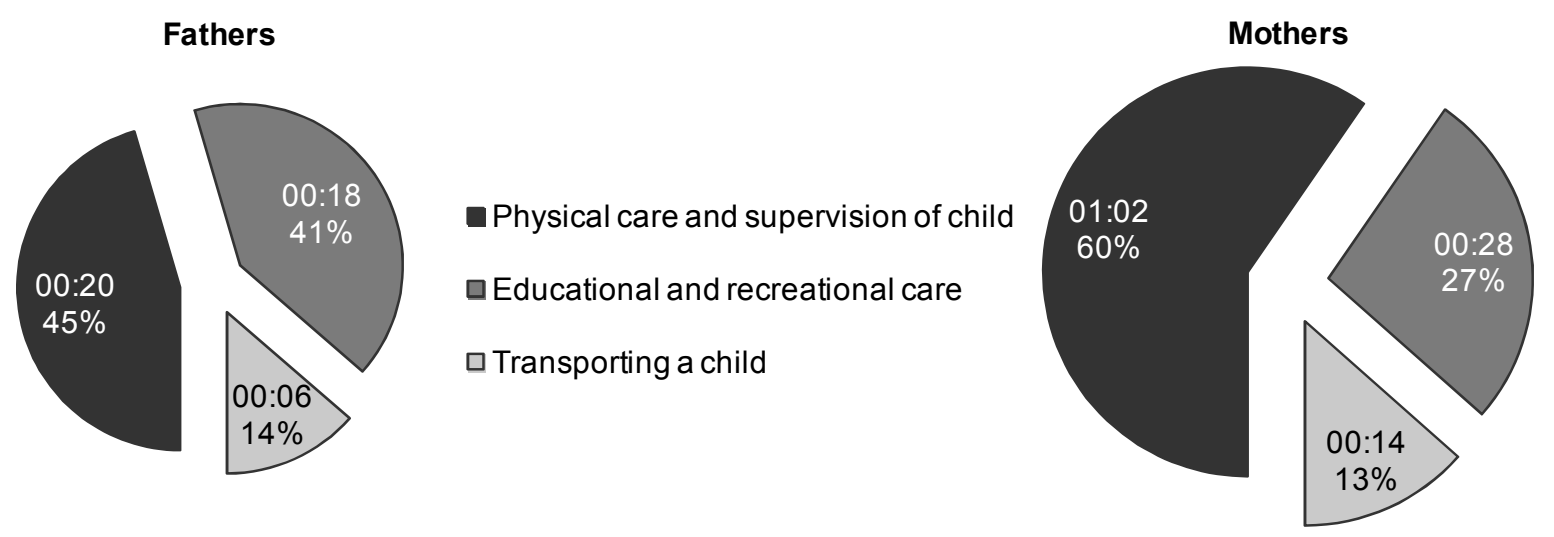

(1) The figures are unweighted averages over the 21 countries for which data is available. The estimates refer to care for children under the age of 18, except for Australia and Canada (under 15 years). See Figure 1 and Figure 8 for country-specific notes.

Source: Secretariat estimates based on national time-use surveys (see Table A1.2 for more details).

\subsection{Care for adults}

32. As with childcare, the time spent on caring for adults is difficult to measure accurately. Care for adults receives much less attention in time-use surveys than care for children does. However, many surveys do not even publish caring for the elderly as a separate category. For instance, the Harmonised European Time Use Survey (HETUS) database, grouping 15 European time-use surveys, includes help to an adult household member under the category "other housework", together with household management (such as paperwork and shopping by phone). In addition, and in contradiction to childcare, adult care is not separated by the age of the person that is being cared for, so it is often impossible to make a distinction between care for an ill or disabled spouse or other relative. Only the Korean time-use survey has separate categories for care for parents, spouse and other family members. Yet, the Korean survey (and also the Japanese survey) does not single out household members, so parents not living in the households are included in the category "care for parents", while this is considered as "care for non-household members" in most other time-use surveys. Differences in definition and presentation thus make the comparison of adult care across countries extremely difficult.

33. Yet, more and better information on the time spent on adult care would contribute to the design and understanding of long-term care policies. Evidence points out that informal care accounts for the largest share in long-term care for elderly and disabled people (OECD, 2011b). In addition, informal care yields several economic, health and social benefits for the care recipient and reduces public long-term care spending. However, while many OECD countries support family and other informal carers either financially, or through respite care and other non-financial benefits, it remains difficult to reconcile work and caring jobs, and informal carers are at a higher risk of poverty (OECD, 2011b).

34. For comparison, Table 2 lists the countries' average duration of adult care according to a range of different classifications used. In the first ten countries, care for adult household members can be separated from care for children, as well as from care for non-household members. In those countries adult care takes up 0.2 to 6 minutes per day. Similar results can be found for Japan and Korea, but it should be kept in mind that these numbers also cover care for family members who do not live in the household. In the Australian 
and Irish time-use surveys, care for household adults cannot be separated from care for non-household adults and the average time spent on adult care is visibly higher in both countries (8-9 minutes). For the twelve surveyed HETUS countries, adult care is classified together with household management under the category "Other domestic work". For most countries, the total time spent on these activities is noticeably higher than in the previously discussed countries. However, in Poland and Slovenia, and to a lesser extent in Finland, France, Italy and the United Kingdom, the total minutes devoted to other domestic work are very low (1-4 minutes per day), suggesting that people spent on average very little time in adult caring. Finally, women devote on average more time to adult caring than men irrespective of the classification used (with the exception of Estonia), but the difference is much smaller than in the case of childcare.

Table 2. Different classification of adult care across countries complicates comparison

Minutes devoted to adult care (excluding travel) for the population aged 15-64 over the period 1998-2009 ${ }^{1}$

\begin{tabular}{l|c|c|c}
\hline & Total $(\boldsymbol{\lambda})$ & Men & Women \\
\hline \multicolumn{3}{c}{ Caring for adult household members } \\
\hline Netherlands & 0.2 & 0.2 & 0.2 \\
\hline South Africa & 0.6 & 0.2 & 1.0 \\
\hline Denmark & 0.8 & 0.9 & 0.8 \\
\hline Austria & 1.2 & 0.5 & 1.8 \\
\hline India & 1.3 & 0.6 & 2.1 \\
\hline United States & 1.9 & 1.5 & 2.4 \\
\hline Canada & 2.0 & 1.0 & 3.0 \\
\hline Portugal & 2.0 & 0.0 & 3.0 \\
\hline Turkey & 3.4 & 3.3 & 3.6 \\
\hline Mexico & 6.0 & 3.0 & 8.8 \\
\hline
\end{tabular}

Caring for adult family members ${ }^{2}$

\begin{tabular}{l|c|c|c}
\hline Japan & 2.9 & 1.0 & 5.0 \\
\hline Korea & 4.0 & 2.0 & 5.0 \\
\hline \multicolumn{4}{|c}{ Caring for adults ${ }^{3}$} \\
\hline Ireland & 8.0 & 3.1 & 13.0 \\
\hline Australia & 9.0 & 7.0 & 11.0 \\
\hline
\end{tabular}

\begin{tabular}{l|c|c|c}
\multicolumn{4}{c}{ Other domestic work $^{4}$} \\
\hline Poland & 1.0 & 1.0 & 2.0 \\
\hline Slovenia & 2.0 & 2.0 & 3.0 \\
\hline Finland & 4.0 & 4.0 & 5.0 \\
\hline France & 4.0 & 4.0 & 4.0 \\
\hline Italy & 4.0 & 3.0 & 4.0 \\
\hline United Kingdom & 4.0 & 4.0 & 4.0 \\
\hline Estonia & 5.0 & 6.0 & 5.0 \\
\hline Belgium & 8.0 & 7.0 & 9.0 \\
\hline Germany & 9.0 & 7.0 & 11.0 \\
\hline Spain & 11.0 & 5.0 & 16.0 \\
\hline Sweden & 11.0 & 10.0 & 13.0 \\
\hline Norway & 12.0 & 11.0 & 13.0 \\
\hline
\end{tabular}

(1) See Figure 1 and Figure 8 for country-specific notes.

(2) Care for adult family members also includes care for family members who do not live in the household.

(3) Care for adults covers both household adults and non-household adults.

(4) Other domestic work includes household management and care for adults.

Source: Secretariat estimates based on national time-use surveys (see Table A1.2 for more details). 
35. The most detailed breakdown of adult care is provided by the American time-use survey (ATUS). From the 2008 ATUS data we can learn that Americans devote on average 2 minutes per day to care for household adults (including travelling) and 5 minutes to non-household members (Table 3). Outside the household, most time goes to helping adults with, for example, routine housework, repair assistance or paperwork, while physical care and medical care are more important within the household. It should be kept in mind, however, that cooking for adult household members is reported under routine housework, while it is categorized under caring for non-household adults. Finally, and contrary to childcare or other housework, caring for adults is more equally divided among men and women.

Table 3. Care for adults in the United States

Breakdown of adult care in the American time-use survey, in minutes per day for the population aged 15-64 (2008)

\begin{tabular}{|c|c|c|c|}
\hline & Total & Men & Women \\
\hline Caring for \& helping household members & 1.95 & 1.49 & 2.40 \\
\hline Caring for household adults & 1.20 & 0.69 & 1.70 \\
\hline 01 Physical care & 0.64 & 0.24 & 1.03 \\
\hline 02 Looking after (as a primary activity) & 0.00 & 0.00 & 0.00 \\
\hline 03 Providing medical care & 0.29 & 0.02 & 0.55 \\
\hline 04 Obtaining medical and care services & 0.10 & 0.16 & 0.04 \\
\hline 05 Waiting associated with caring & 0.16 & 0.27 & 0.05 \\
\hline 99 Caring, n.e.c. & 0.01 & 0.00 & 0.02 \\
\hline Helping household adults & 0.75 & 0.80 & 0.69 \\
\hline 01 Helping & 0.15 & 0.14 & 0.16 \\
\hline 02 Organization \& planning & 0.09 & 0.08 & 0.11 \\
\hline 03 Picking up/dropping off & 0.20 & 0.18 & 0.22 \\
\hline 04 Waiting associated with helping & 0.16 & 0.14 & 0.18 \\
\hline 99 Helping, n.e.c. & 0.13 & 0.25 & 0.02 \\
\hline Caring for \& helping non-household members & 4.64 & 4.63 & 4.66 \\
\hline Caring for non-household adults & 0.72 & 0.38 & 1.06 \\
\hline 01 Physical care & 0.14 & 0.06 & 0.21 \\
\hline 02 Looking after (as a primary activity) & 0.05 & 0.08 & 0.02 \\
\hline 03 Providing medical care & 0.10 & 0.01 & 0.20 \\
\hline 04 Obtaining medical and care services & 0.24 & 0.13 & 0.34 \\
\hline 05 Waiting associated with caring & 0.15 & 0.10 & 0.20 \\
\hline 99 Caring, n.e.c. & 0.05 & 0.00 & 0.10 \\
\hline Helping non-household adults & 3.92 & 4.25 & 3.59 \\
\hline 01 Housework, cooking, \& shopping assistance & 0.66 & 0.56 & 0.77 \\
\hline 02 House \& lawn maintenance \& repair assistance & 0.95 & 1.37 & 0.55 \\
\hline 03 Animal \& pet care assistance & 0.14 & 0.08 & 0.20 \\
\hline 04 Vehicle \& appliance maintenance/repair assistance & 0.32 & 0.54 & 0.10 \\
\hline 05 Financial management assistance & 0.05 & 0.05 & 0.05 \\
\hline 06 Household management \& paperwork assistance & 0.56 & 0.51 & 0.60 \\
\hline 07 Picking up/dropping off & 0.47 & 0.43 & 0.50 \\
\hline 08 Waiting associated with helping & 0.19 & 0.16 & 0.22 \\
\hline 99 Helping, n.e.c. & 0.57 & 0.54 & 0.61 \\
\hline Total caring for adults & 6.59 & 6.12 & 7.05 \\
\hline
\end{tabular}

Source: American Time-Use Survey 2008. 


\section{Participation rates and time spent by participants}

36. The data presented above provide information on the average time use for all people (within the age category 15-64 years). However not everybody does unpaid work. It is thus interesting to look at both the participation rates in different types of unpaid work and the time spent in those activities by those who actually perform the activity. This section focuses on two unpaid activities in particular, i.e. volunteering and cooking.

\subsection{Voluntary work}

37. As already mentioned above, little time is spent on average on volunteering, ranging from less than 1 minute per day in Hungary, India and South Africa to 13 minutes in New Zealand. The low population means are reflected in the low share of the population that actually participate in voluntary work, on average $2.9 \%$ of the population in the 26 countries (Figure 11, Panel A). ${ }^{6}$ At the top of the ranking we find New Zealand, where $8.8 \%$ of the population aged 15-64 engages in voluntary work, followed by the United States and Ireland, with a participation rate of $6.3 \%$. The cross-country variation of volunteering time as reported in the time-use surveys is comparable to the information provided by the Gallup data on volunteering time (CAF, 2010), as show by their correlation coefficient of 0.67.

38. When we compare the participation rates with the participation time - the average time for those who in fact performed the activity - the picture is completely different. Across the 26 countries under consideration, volunteers devote on average two hours per day to voluntary work (Figure 11, Panel B). Thus, while very few people are engaged in volunteering, those who are, devote a lot of time to the task.

\subsection{Cooking and food clean-up}

39. A similar exercise can be done for cooking and food clean-up. Purchasing meals is a typical way of reducing the time spent on routine housework. On average in the 28 countries for which data are available, ${ }^{7} 64 \%$ of the population cooks on an average day, with the participation rate ranging from a minimum of $44 \%$ in Ireland and India to more than $75 \%$ in the Nordic countries. Yet, the opposite ranking is found for the actual cooking time conditional on participation (Figure 12, Panel B). Less than half of the adults cook in India, but those who do, spend nearly 3 hours per day in the kitchen. In Norway and Denmark, on the other hand, the large majority of the population engages in cooking, but they devote barely one hour to it.

The United States is the only country where both the participation rate and mean time amid participants are at the bottom of the ranking. In other words, the American population attaches on average little importance to cooking relative to the other surveyed countries. The United States is also one of the countries where relatively little time is spent eating as a primary activity and where obesity rates are amongst the highest in the OECD (see Society at a Glance 2009). ${ }^{8}$

6. There is no information on the participation rates and time for voluntary work for Australia, Portugal and Turkey.

7. Participation rates for cooking and clean-up are not available for Hungary.

8. From a cross-country perspective, the relationship between eating and cooking is less clear-cut. The correlation coefficient for cooking time and eating is -0.05 for all respondents. 
Figure 11. Very few people engage in voluntary work, but volunteers devote a lot of time ${ }^{1}$

Panel A: Participation rates in volunteering, \% of the population

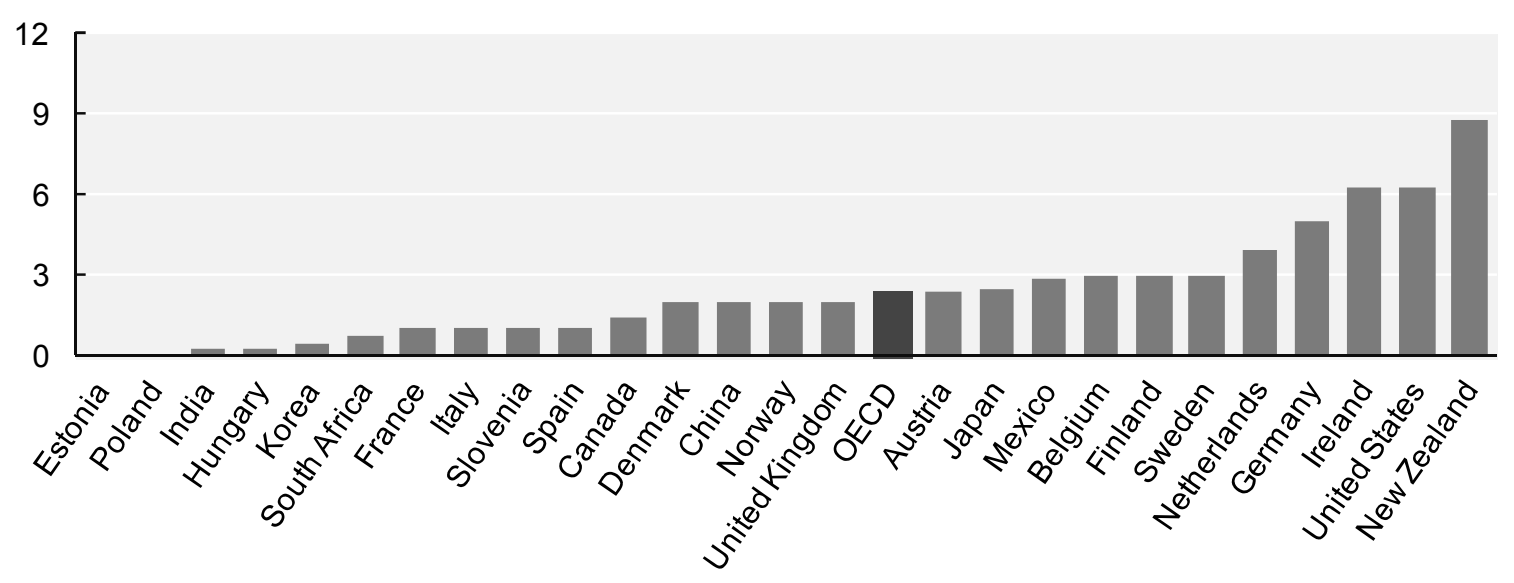

Panel B: Average minutes of volunteering per day by all respondents and volunteers only

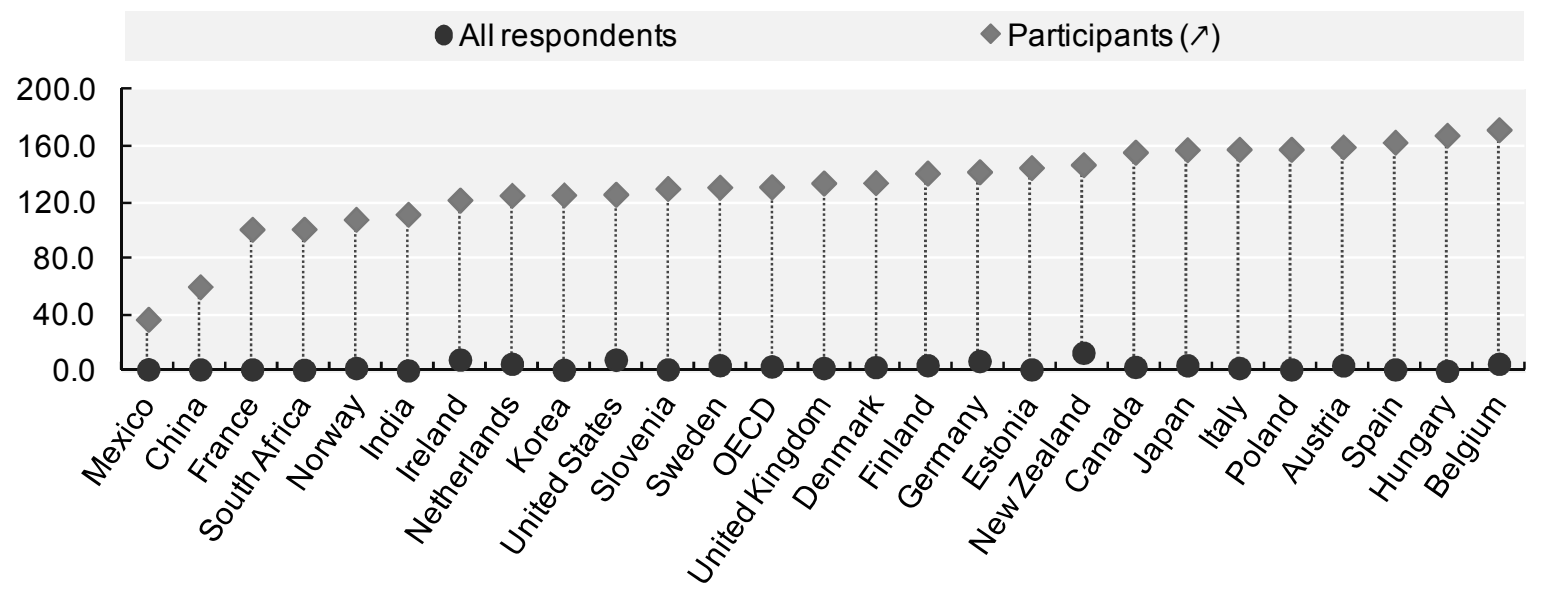

(1) Participation rates and time for the population aged 15-64 over the period 1998-2009. See Figure 1 for country-specific notes. Source: Secretariat estimates based on national time-use surveys (see Table A1.2 for more details). 
Figure 12. Fewer people cook in India, but those who do spend of a lot of time cooking ${ }^{1}$ Panel A: Participation rates in cooking and food clean-up, \% of the population

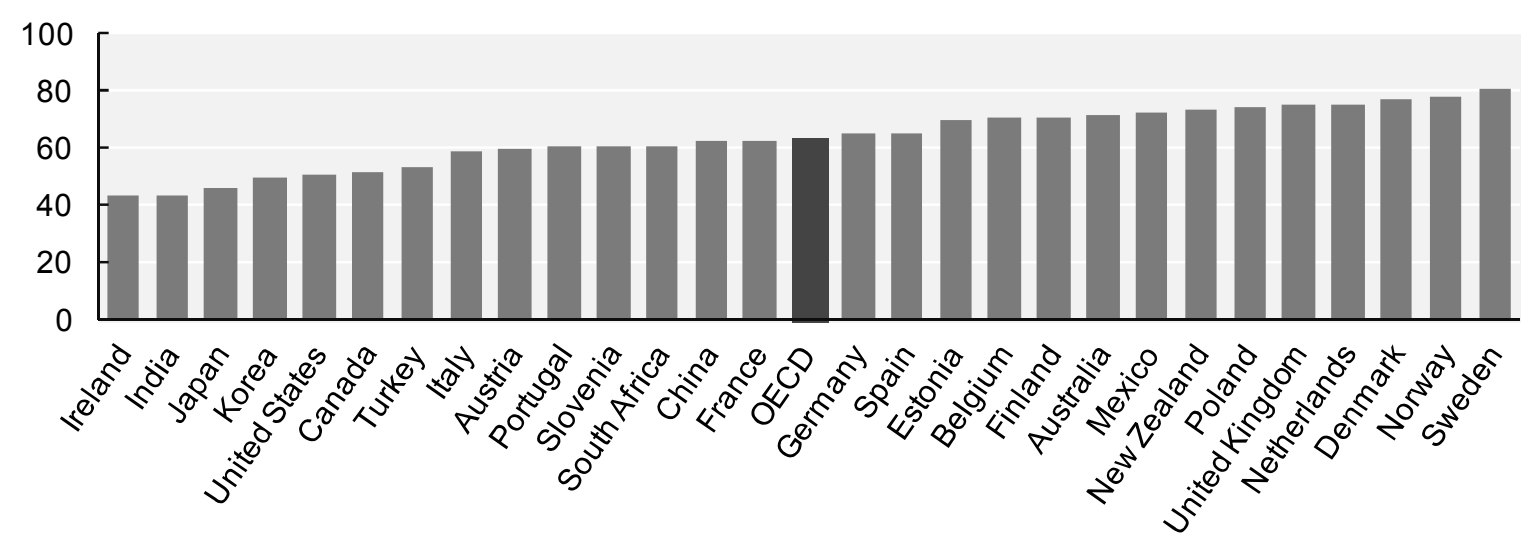

Panel B: Average minutes per day spent on cooking and food clean-up by all respondents and participants only

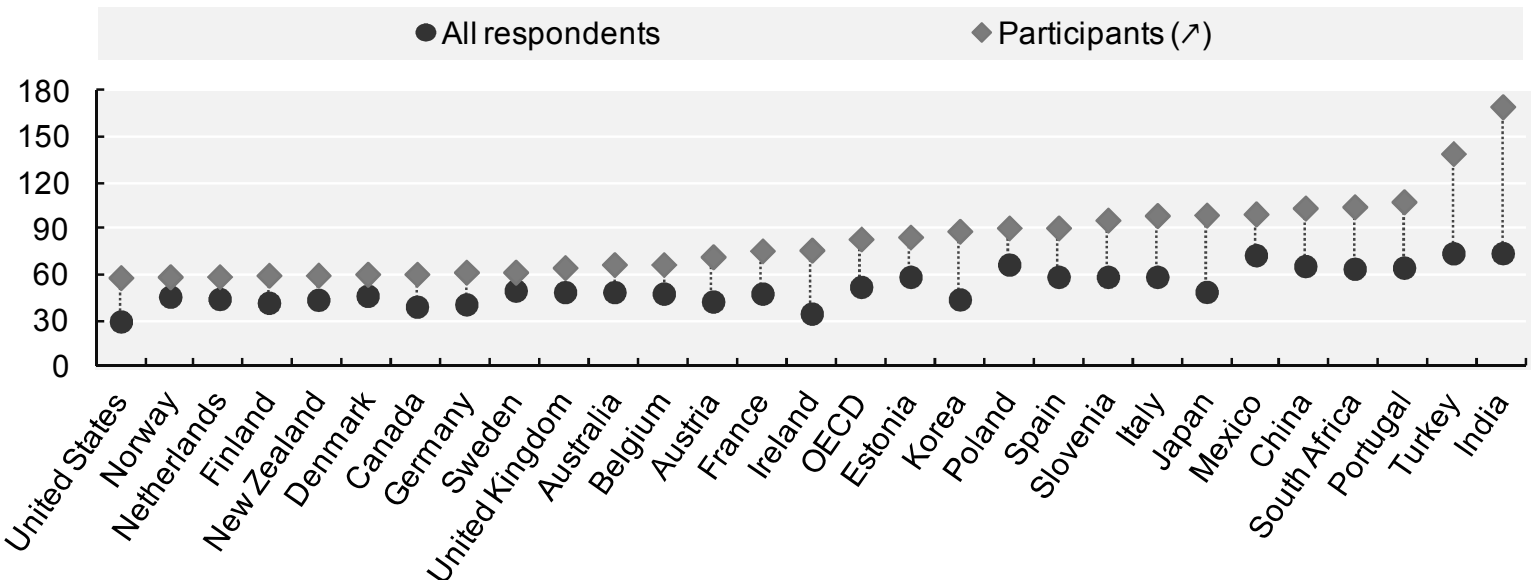

(1) Participation rates and time for the population aged 15-64 over the period 1998-2009. See Figure 1 for country-specific notes.

Source: Secretariat estimates based on national time-use surveys (see Table A1.2 for more details).

\subsection{Gender differences by type of unpaid work}

40. Not only are women more involved in unpaid work, also the kind of activities in which they engage differs from their male counterparts. The most typical male tasks in the household are construction and repair work where women's involvement is limited, both in terms of participation and the amount of time they devote to the task (Figure 13). Men also devote slightly more time to gardening and pet care, but their participation rates in these activities are more or less equal to those of women. Tasks that have traditionally been thought of "women's work" (e.g. cooking and cleaning) continue to be primarily performed by women. In the countries surveyed, $82 \%$ of women prepare meals on an average day, while only $44 \%$ of men do. Also the average time spent by women on cooking is four times the time spent by men (Figure 13, Panel B). 
Figure 13. Women cook and clean while men are responsible for gardening, pet care and repairing ${ }^{1}$

Panel A: Percentage of men and women aged 15-64 performing the task, OECD averages over the period 1998-2009
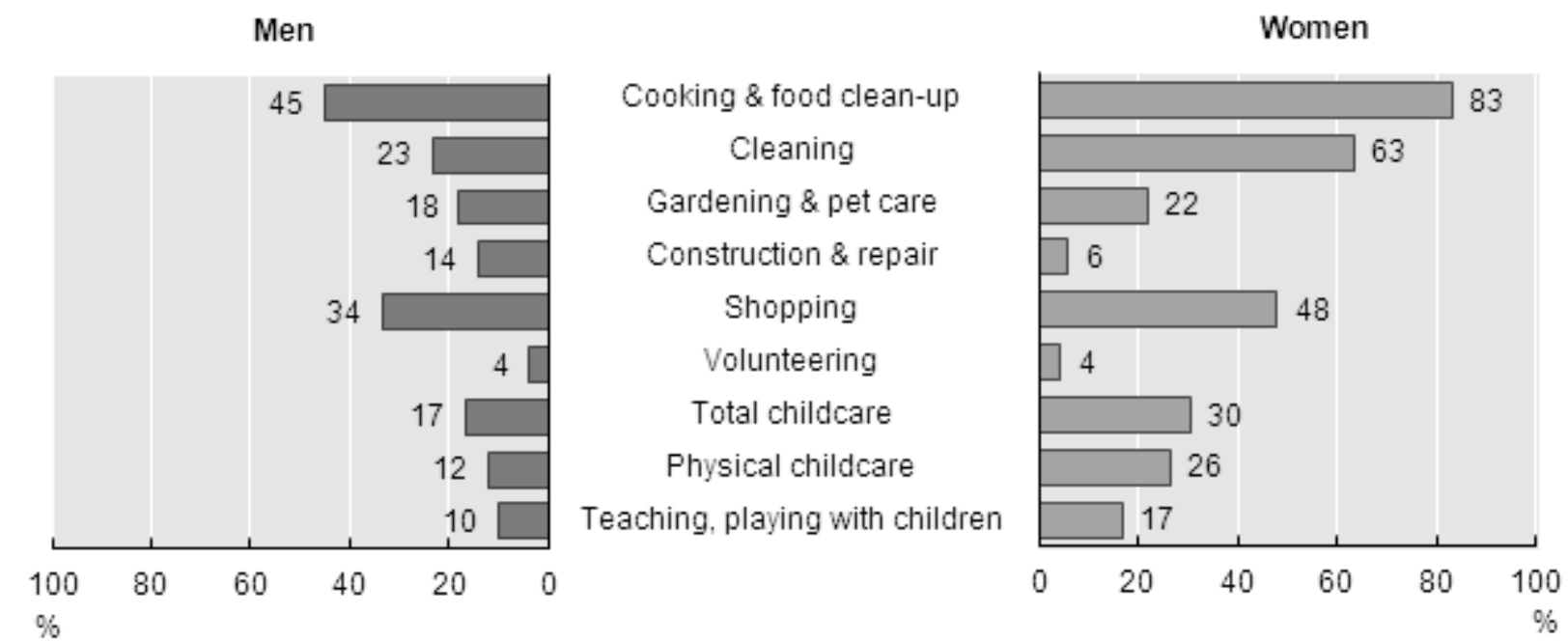

Panel B: Minutes per day devoted to the activity by men and women aged 15-64, OECD averages over the period $1998-2009^{2}$
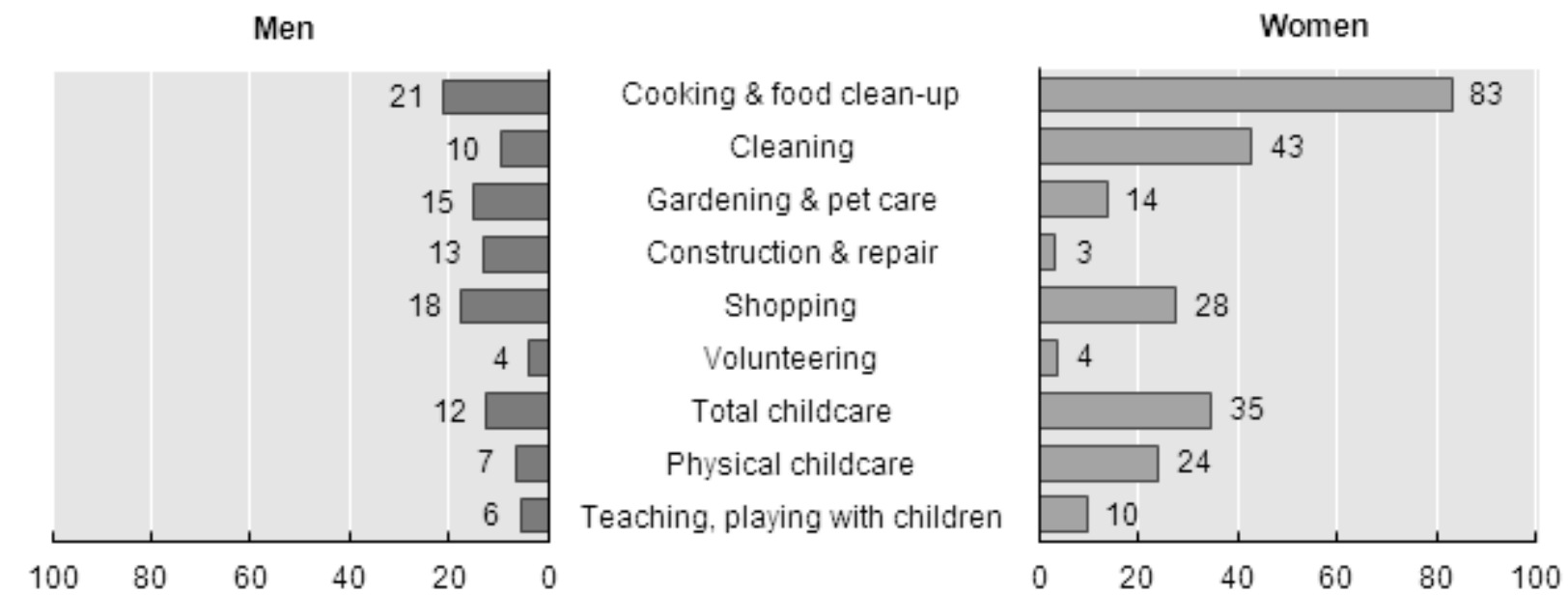

(1) See Figure 1 and Figure 8 for country-specific notes. The percentages are unweighted averages over the 29 countries for with data is available.

(2) The statistics presented in Panel B reflect the average time use for all people, including those who do not perform the task.

Source: Secretariat estimates based on national time-use surveys (see Table A1.2 for more details).

\section{Time use by socioeconomic characteristics}

41. The unpaid working time and pattern vary substantially between age groups. On average across the 28 countries covered in this study, young people (aged 15 to 24 years) devote 110 minutes per day to unpaid work, compared to 229 minutes for the working-age population (aged 25 to 64 years) and 241 minutes for elderly (aged 65 and more). Figure 14 illustrates that youth spend considerably less time on unpaid work in all countries, whereas the unpaid working time is rather similar for the working-age 
population and elderly in most countries. A further look at the data reveals that the lower unpaid working time among young people is compensated by longer hours of education, leisure and sleep.

42. While total time devoted to unpaid work among people aged 65 and more is not very different from that of the working-age population, the type of unpaid activities differs considerably. On average in the 28 countries, elderly devote nearly half an hour less to care for household members and travel slightly less. Instead, they spend more than half an hour extra per day on routine housework and shopping and nearly double their volunteering time. ${ }^{9}$ The extra time devoted to shopping and cooking is confirmed by Aguilar and Hurst (2007) who argue that individuals will substitute away from market expenditures as the relative price of time falls. Their study also shows that older households tend to increase their shopping frequency to exploit store discounts.

Figure 14. Elderly and people of working age have a similar unpaid working time while youth do significantly less

Minutes of unpaid work by age group for the population aged 15 and more over the period 1998-2009 ${ }^{1}$

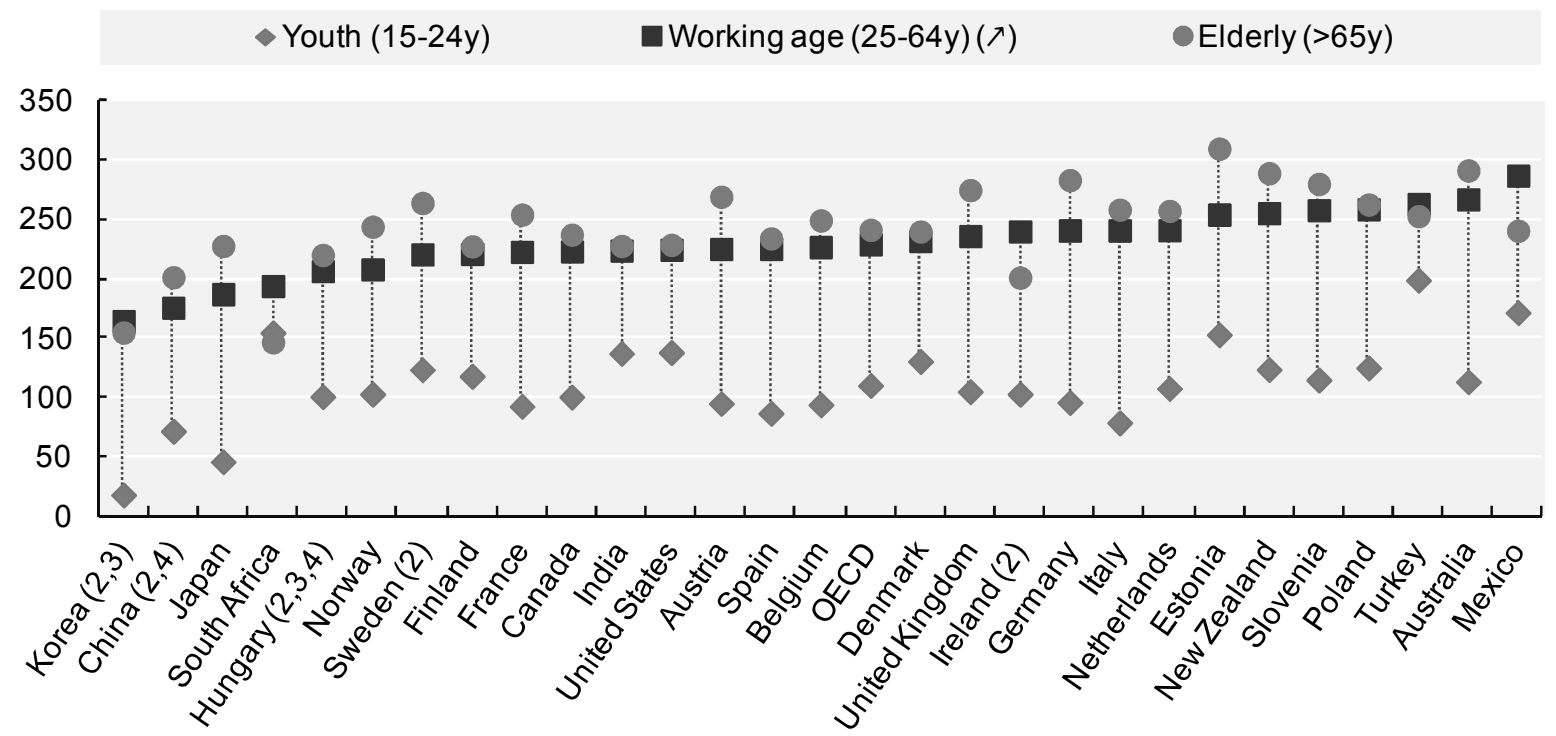

(1) See Figure 1 and Figure 8 for country-specific notes. For Portugal, it was not possible to distinguish by age.

(2) Youth generally covers time use of individuals in the age category 15-24 years, except for Hungary (15-19y), Ireland (18-24y), Korea (10-19y), and Sweden (20-24y). For China, the time-use estimates for youth are unweighted averages of the age categories $15-19 y$ and $20-24 y$.

(3) Working-age includes time use of individuals in the age category 25-64 years, except for Hungary (25-59y) and Korea (30-59y). In addition, the Korean time-use estimates for the working-age population are unweighted averages of the age categories 30-39y, 40$49 y$ and 50-59y.

(4) Elderly includes time use of people older than 65 years, except for Hungary (60-74y)). For China, the time-use estimates for the elderly are unweighted averages of the age categories 65-69y and 70-74y.

Source: Secretariat estimates based on national time-use surveys (see Table A1.2 for more details).

43. In addition, time use markedly depends on a person's labour force activity status. Splitting the male samples into full-time employed, unemployed and retired men, illustrates that the latter two groups have a higher unpaid working time than the former group. In particular, the time devoted to routine housework and care for non-household members doubles for both unemployed and retired men. These

9. See also the Sloan Center on Aging \& Work (2010) for a discussion on the increase in volunteering time among older adults. 
results are consistent with the unemployed and retired men having a lower opportunity cost of time (Krueger and Mueller, 2008).

Figure 15. Retired men do more unpaid work than full-time employed, while the evidence for unemployed men is mixed

Minutes of unpaid work for men by labour force status for the population aged 15 and more over the period 1998-2009 1

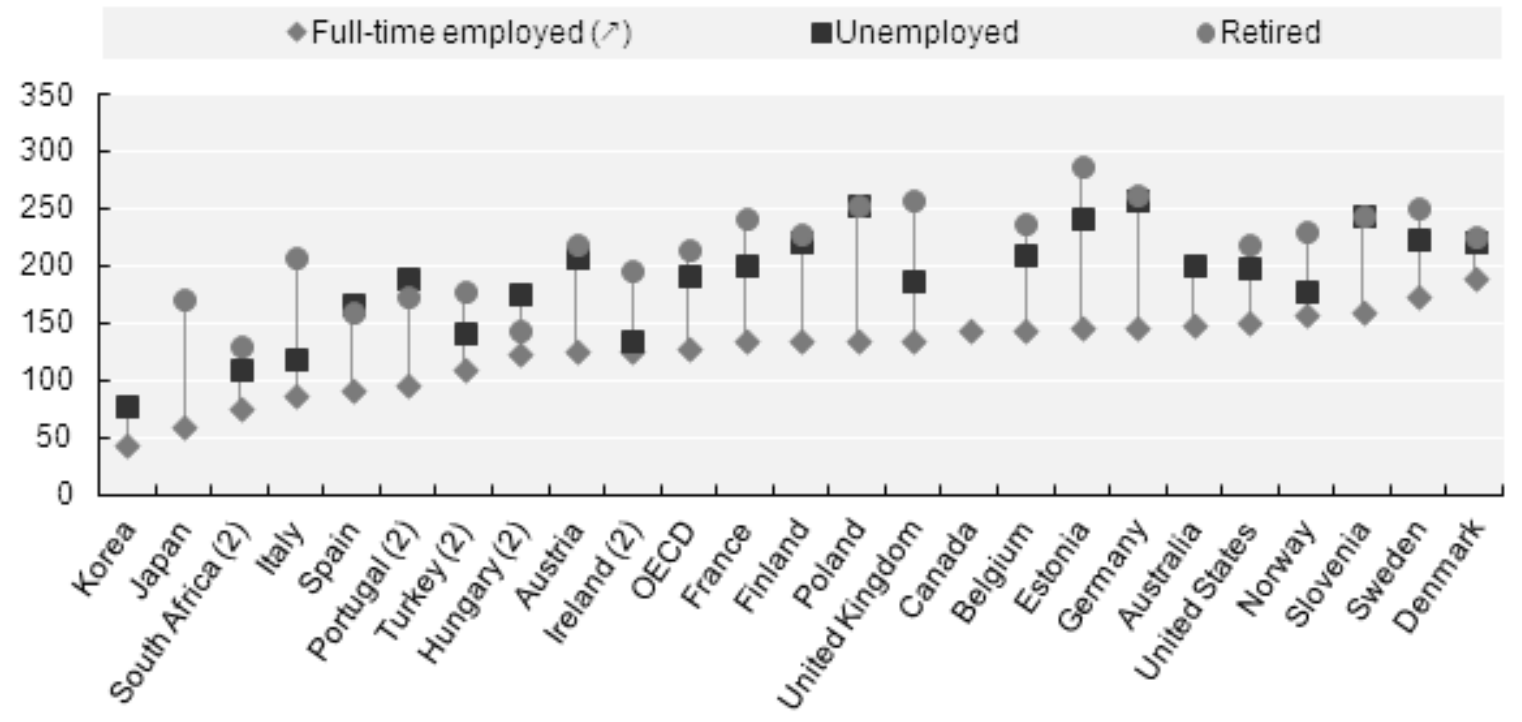

(1) See Figure 1 and Figure 8 for country-specific notes. For China, India, Mexico and the Netherlands, it was not possible to distinguish by labour force status.

(2) For Hungary, Ireland, Portugal, South Africa and Turkey it was not possible to distinguish full-time employed men from part-time employed men, so for these countries, the time use of all employed men is presented instead.

Source: Secretariat estimates based on national time-use surveys (see Table A1.2 for more details).

\section{Value of the time devoted to household production}

44. The literature on unpaid work proposes two approaches for imputing a monetary value to the time household members devote to household production: the opportunity-cost approach and the replacement-cost approach. ${ }^{10}$

45. The opportunity-cost approach values the time devoted to household production at the wage rate that a household member could have earned on the labour market. The underlying assumption is that the household member has foregone some earnings for home production. This approach tends to overstate, however, the contribution of the household sector to a country's output since household production is not considered to require high qualifications. For instance, applying a lawyer's wage to value the time walking the family dog would attribute a high price to a low-skilled activity. Besides, some household production is generated by individuals who do not have a wage - such as housewives, unemployed people or retiree. Although their wage rate could be imputed using wages rates of workers with similar qualifications and other observed characteristics, it can be argued that these individuals would not necessarily be able to find a job on the market according to their qualifications.

10. See Ironmonger (2001), Abraham and Mackie (2005) and Folbre (2009). 
46. The replacement-cost approach considers what it would cost to hire a worker to perform the activity, by using either a specialist's wage or a generalist's wage. Using a specialist's wage for each household task - e.g. a plumber's wage to fix a leak or a gardener to trim the hedge - would also overestimate the value of the input by household members since specialists work more efficiently than household members can and need less time to perform the same task. Besides, detailed time-use estimates for each activity are required, which is not the case for all countries. Instead, the generalist wage approach applies the wage rate of a domestic servant or handyman to value the time devoted to all household unpaid activities.

47. For comparison, this study uses both the opportunity-cost approach and the replacement-cost approach. In the former, a country's average hourly wage is used to value unpaid household work, while the average hourly wage cost for unregistered (informal) activities is used in the latter. In both approaches, the estimates of hourly wages are net of taxes and social contributions and only primary activities are taken into account. ${ }^{11}$

48. Figure 16 presents the value of labour devoted to household production of non-market services as a percentage of GDP for 25 OECD countries. The replacement-cost approach suggests that the labour devoted to unpaid work accounts for 19\% of GDP in Korea up to 53\% of GDP in Portugal. The upperbound estimates are provided by the opportunity-cost approach. Simple country averages of both approaches suggests that between one-third and half of all valuable economic activity in the OECD area is not accounted for in the system of national accounts. To the extent that those large populations under age 15 and over age 64 undertake unpaid work, these will be under-estimates.

\section{Figure 16. Unpaid work accounts for one-third of all valuable economic activity in the OECD member} countries

Household production of non-market services, labour costs, in percentage of GDP ${ }^{1}$

Panel A: Replacement-cost approach ${ }^{2}$

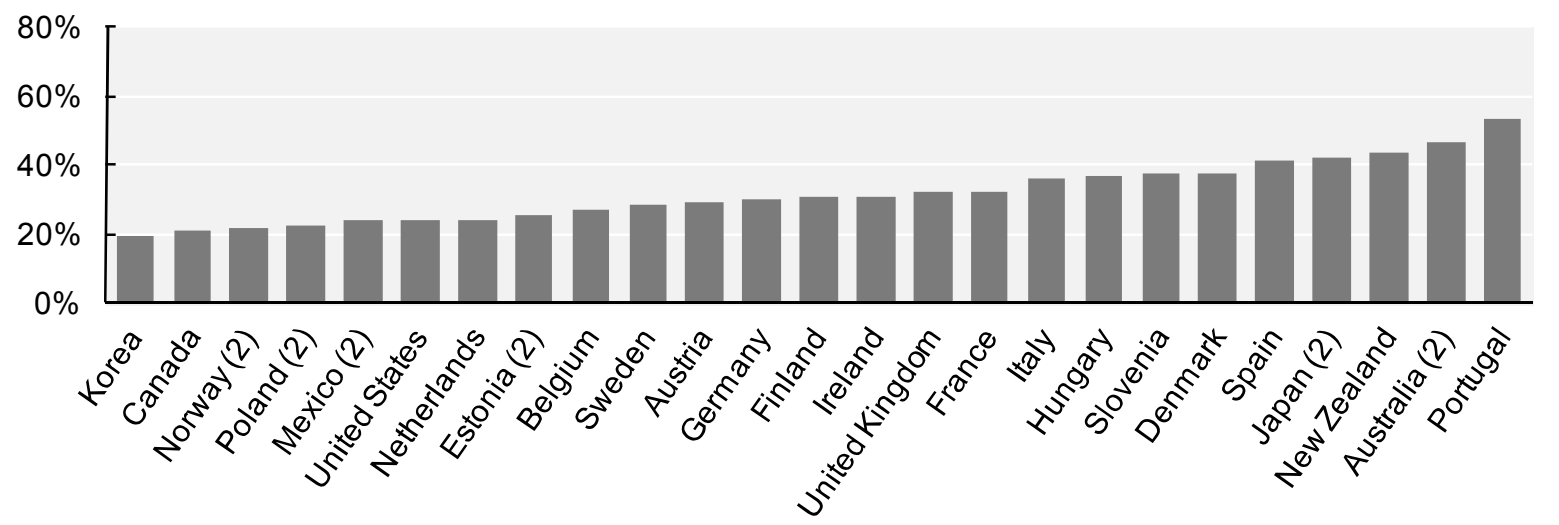

11. For more detailed information on the methodology and data sources, see the forthcoming OECD Statistics Directorate Working Paper: Incorporating Household Production into International Comparisons of Material Well-Being (Ahmad and Koh, 2011). 
Panel B: Opportunity-cost approach ${ }^{3}$

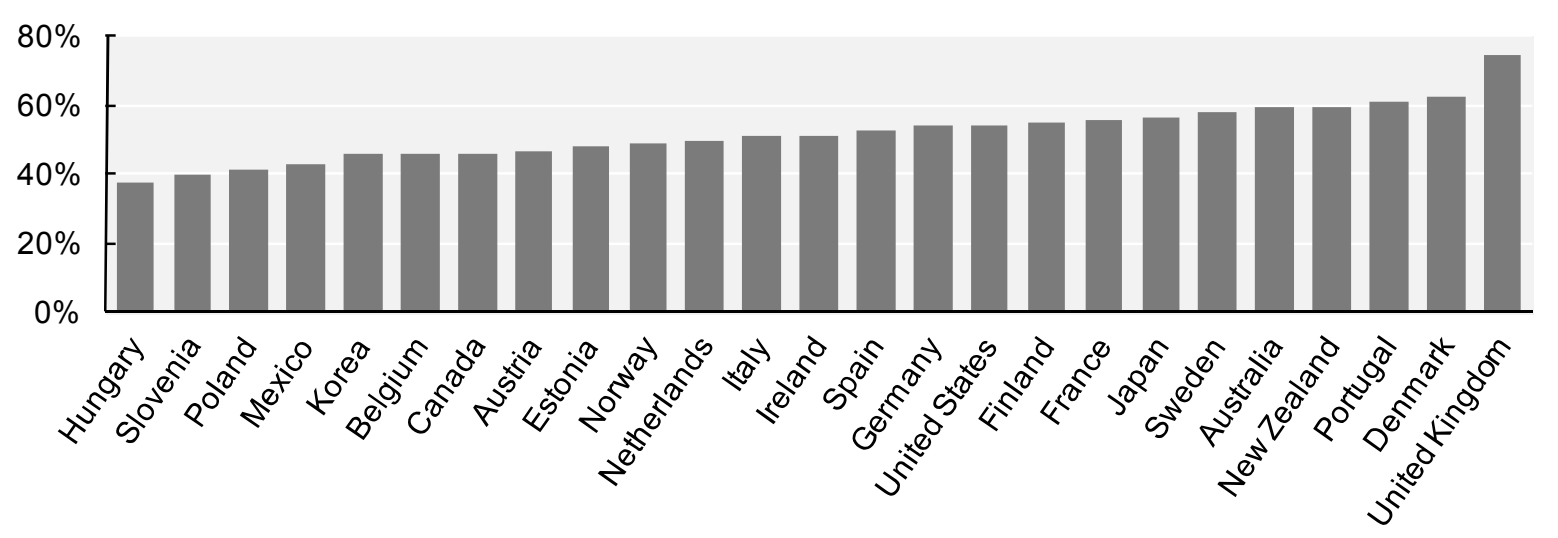

(1) Time-use estimates for the population aged 15-64 over the period 1998-2009 are used and only primary activities are taken into account. See Figure 1 for country-specific notes.

(2) A country's average hourly wage cost for unregistered (informal) activities is used to value unpaid household work. For several countries, this information was not available. Instead, the following wage costs are used: wages costs for registered activities adjusted for tax and social security contributions (Australia and Japan); $50 \%$ of the average net wage for the total economy (Estonia and Mexico and Poland); the average hourly wage of a child care worker adjusted for tax and social contributions (Norway).

(3) The country's average hourly wage is used to value unpaid household work.

Source: Secretariat estimates based on national time-use surveys (see Ahmad and Koh, 2011).

\section{Conclusion}

49. Unpaid work matters a great deal. As shown in this paper, unpaid work - largely dominated by cooking, cleaning and caring - is an important contributor to societal well-being in ways that differ both between countries and between men and women. Our calculations suggest that between one-third and half of all valuable economic activity in OECD countries is not accounted for in the traditional measures of well-being, such as GDP per capita. Unpaid work contributes not only to current household consumption (e.g. cooking) but also to future well-being (e.g. parental investments in raising children) and to community well-being (e.g. voluntary work). In all countries, women do more of such work than men, although to some degree balanced - by an amount varying across countries - by the fact that they do less market work.

50. While unpaid work - and especially the gender division of unpaid work - is to some extent related to a country's development level, country cross-sectional data suggest that demographic factors and public policies tend to exercise a much larger impact. The regular collection of time-use data can thus be of tremendous value for government agencies to monitor and design public policies, and give a more balanced view of well-being across different societies. In particular, learning about people's time allocation ensures a better understanding of a society for policymakers concerned with efficiency and equity of social policies. The consideration of unpaid work for relative inequality and for inequality over time is not directly addressed in this paper, but such work may be part of a future agenda for the OECD as new timeuse surveys become available for many countries in the next few years. 


\section{REFERENCES}

Abraham, K. and C. Mackie (2005), Beyond the Market: Designing Nonmarket Accounts for the United States, The National Academies Press, Washington, D.C.

Aguilar, M. and E. Hurst (2007), "Life-Cycle Prices and Production", American Economic Review, Vol. 97, No. 5, pp.1533-1559.

Ahmad, N. and S. Koh (2011), "Incorporating Household Production into International Comparisons of Material Well-Being”, OECD Statistics Directorate Working Paper, Paris, forthcoming.

Baker, M. (1997), "Parental Benefit Policies and the Gendered Division of Labour", Social Service Review, Vol.71, No.1, pp.52-71.

Becker, G. (1965), “A Theory of the Allocation of Time”, Economic Journal, Vol.75, No.299, pp. 493517.

Budig, M. and N. Folbre (2004), “Activity, Proximity or Responsibility? Measuring Parental Childcare Time", in Folbre, N. and M. Bittman (eds.), Family Time, the Social Organization of Care, Routledge, New York.

CAF (2010), The World Giving Index 2010, Charities Aid Foundation, United Kingdom.

Ehrenreich, B. and A. Russell Hochschild (2003), Global Woman: Nannies, Maids, and Sex Workers in the New Economy, Metropolian Books, New York.

Frazis, H. and J. Stewart (2010), "How Does Household Production Affect Measured Income Inequality?" Journal of Population Economics, forthcoming.

Freeman, R. and R. Schettkat (2005), "Marketization of Household Production and the EU-US Gap in Work", Economic Policy, Issue 41 (January), pp.6-50.

Folbre, N. (2009), "Inequality and Time Use in the Household", in Salverda, W., Nolan, B. and T. Smeeding (eds.), Oxford Handbook of Economic Inequality, Oxford University Press.

Folbre, N. and J. Yoon (2007), "What is Child Care? Lessons from Time-Use Surveys of Major EnglishSpeaking Countries", Review of Economics of the Household, Vol.5, No.3, pp.223-248.

Gornick, J. and M. Meyers (2003), Families that Work: Policies for Reconciling Parenthood and Employment, New York, Russell Sage.

Guryan, J., E. Hurst and M. Kearney (2008), "Parental Education and Parental Time with Children", Journal of Economic Perspectives, Vol. 22, No. 3, pp.23-46.

Hill, T. (1979), “Do-It-Yourself and GDP”, Review of Income and Wealth, Vol.25, No.1, pp.31-39.

Hook, J. (2006), “Care in Context: Men's Unpaid Work in 20 Countries, 1965-2003”, American Sociological Review, Vol.71, No.4, pp.639-660. 
Ironmonger, D. (1996), "Counting Outputs, Capital Inputs and Caring Labor: Estimating Gross Household Product", Feminist Economics, Vol.2, No.3, p.37-64.

Ironmonger, D. (2001), "Household Production", in Smelser, N. and B. Baltes (ed.), International Encyclopedia of the Social \& Behavioral Sciences, Elsevier Science, pp. 6934-6939.

Jaumotte, F. (2003), "Female Labour Force Participation: Past Trends and Main Determinants in OECD Countries", OECD Economics Department Working Papers, No. 376 (December 12), Paris.

Krueger, A. and A. Mueller (2008), "The Lot of the Unemployed: A Time Use Perspective”, IZA Discussion Paper, No. 3490, Institute for the Study of Labor, Bonn.

Lewis, J., Campbell, M. and C. Huerta (2008), "Patterns of Paid and Unpaid Work in Western Europe: Gender, Commodification, Preferences and the Implications for Policy", Journal of European Social Policy, Vol.18, No. 21, pp.21-37.

OECD (2007), Babies and Bosses, Organisation for Economic Co-operation and Development, Paris.

OECD (2009), Society at a Glance, Organisation for Economic Co-operation and Development, Paris.

OECD (2011a), Doing Better for Families, Organisation for Economic Co-operation and Development, Paris.

OECD (2011b), Health Wanted? Providing and Paying for Long-Term Care, Organisation for Economic Co-operation and Development, Paris.

Sayer, L., Gauthier, A. and F. Furstenberg (2004), "Educational Differences in Parents' Time with Children: Cross-National Variations", Journal of Marriage and Family, Vol. 66, pp.1152-1169.

Sloan Center on Aging \& Work (2010), "Trends in Volunteerism among Older Adults", Fact Sheet 03 (January), Boston College, http://www.bc.edu/ageingandwork.

Stiglitz, J., Sen, A. and J.-P. Fitoussi (2007), "Report by the Commission on the Measurement of Economic Performance and Social Progress", http://www.stiglitz-sen-fitoussi.fr.

Weinrobe, M. (2005), "Household Production and National Production: An Improvement of the Record", Review of Income and Wealth, Vol.20, No.1, pp.89-102. 
DELSA/ELSA/WD/SEM(2011)1

\section{ANNEX A1: MAIN FEATURES OF TIME-USE SURVEYS}

51. Time-use surveys are the primary statistical vehicle for recording information on how people precisely allocate their time across different day-to-day activities. Typically, a large number of people keep a diary of activities over one or several representative days for a given period. Respondents describe their activities in their own words in a time diary and these are then re-coded by national statistical agencies into a set of descriptive categories. A well-designed survey classifies activities across a total duration of 24 hours (or 1440 minutes) per day.

52. Interest in time-use studies has grown considerably over the last 20 years and an increasing number of national statistical agencies have been conducting large-scale time-use surveys. Most time-use data sets are large enough to generate reliable measures of time allocation over the full year, but the accuracy of these estimates as well as the methodology vary significantly from country to country. Differences in survey features, number of diary days sampled, and categorisation of activities may all affect the cross-country comparability of results. The most important dimensions along which time-use surveys differ at discussed below, with an overview presented in Table A1.2.

\section{A1.1. Sample design}

53. All time-use surveys included in this chapter are based on nationally representative samples of resident non-institutionalised populations. National surveys differ, however, in terms of sample design, with some surveys relying on a random sample and others using a pre-established sample taken from other large-scale population surveys. Time-use surveys also differ in terms of sample size (from around 1000 people in Ireland to about 47000 people in Italy and Spain), age of respondents included in the sample (usually those aged 15 and over, but with several exceptions) and response rates (because of the large nonresponse rates, some surveys reweight the actual number of completed time-use diaries in order to take into account potential non-respondents). Time-use survey also differ in terms of the demographic characteristics that are collected, in how these characteristics are defined (e.g. labour force status), and in terms of the contextual information provided for each activity (e.g. where they were performed, whether additional people were present at that time, etc.).

\section{A1.2. Time-use recording}

54. Most countries use a 24-hour diary in which respondents precisely record in their own words their activities, with the length of the time slots (1-15 minutes) varying across countries. Ireland and Mexico, on the other hand, utilise a simplified variant of the time-use diary. In Ireland, respondents are required to indicate on a list of 26 pre-coded activity categories which activities they were involved in for each 15 minutes period of the day. While pre-coded categories make it much easier for the respondents to fill out, this diary type provides less detailed information and leaves it up to the respondents to decide in which category a particular activity fits. In the case of Mexico, respondents are asked 79 questions about their time use during the seven days prior to the interview. Given the large time lapse between the activity and the interview, the responses are likely to be rather rough estimates of the true time use. In addition, the type of questions is likely to influence the time-allocation outcomes of the survey. For instance, there are five questions on physical childcare (a typical female activity, see section 4.2), while there is no question on playing with children (a typical male activity). 


\section{A1.3. Activity classification}

55. Surveys classify the respondents' verbal and/or written descriptions of their activities into a set of broader categories. Since these coding systems vary according to the survey's goals and ambitions, they lead to classifications with different degrees of detail. Differences in categorisation stem mainly from choices made to allocate certain activities into broader categories. For instance, some surveys regroup all purchasing activities into one "shopping" category, while others differentiate according to the purpose of the purchases (i.e. purchasing groceries, office supplies, household objects/services, etc.). Some surveys categorise sports and volunteer activities into a broad "socialising and leisure" category, while others separate individual leisure activities (computer-gaming) from collective leisure activities (participating in a sports match). Some surveys include civic and religious activities under "other activities" while others omit them entirely. Some surveys include the time spent responding to the survey, while others do not. Finally, some surveys include a separate category for time spent travelling, sometimes divided according to the purpose of the travelling (i.e. travelling to and from work or travelling for a holiday), while others include travelling time in the broader category to which they are linked.

\section{A1.4. Number of diary days}

56. Different methodological choices are made in order to determine the number of diary days to be completed by each participant. For example, the United States survey (ATUS) asks each respondent to complete a time diary for only one day, but most surveys typically obtain data for two days. Both options have their pros and cons. The time spent on various activities on any particular day may not be representative of how respondents typically spend their time, although such anomalies should average out across the full sample of respondents. Conversely, time-budget information for several days allows addressing issues related to how activities are combined over several days, although this comes at the cost of depressing response rates. In general, the relative value of having multiple reports from each particular respondent as opposed to single reports from a larger number of respondents depends on the general objective of the survey.

\section{A1.5. Period over which the survey is conducted}

57. Time-use responses are generally representative of activities in which people engage on the days of the week for which they complete time budgets. For most countries, the time-use surveys are spread over the whole year and thus provide accurate estimates for the full year. Others cover particular periods in the year, which are typically chosen to avoid seasonal biases such as those due to public holidays or annual leave for workers. This is the case, to varying degrees, for Canada, China, Denmark, France, Ireland, Japan, Korea, Mexico and South Africa. The exclusion of holiday periods may, however, lead to an overestimation of annual paid working time and an underestimation of unpaid work and leisure time, as illustrated in Table A1.1. In all four countries represented in the table, people do less paid work on weekend days than on weekdays, while the opposite is true for unpaid work and leisure. The different choices made with respect to the survey period typically depend on the goals, the practical capabilities and the financial resources of statistical institutes. 
DELSA/ELSA/WD/SEM(2011)1

Table A1.1 People do more unpaid work on weekends than on a weekday

24-hour breakdown of time spent in main activities on weekdays and weekend days, in percentage of total time use

\begin{tabular}{|c|c|c|c|c|c|c|c|c|}
\hline & \multirow{2}{*}{\multicolumn{2}{|c|}{$\begin{array}{c}\text { China } \\
\text { Weekday Weekend }\end{array}$}} & \multicolumn{2}{|c|}{ France } & \multicolumn{2}{|c|}{ Japan } & \multicolumn{2}{|c|}{ Korea } \\
\hline & & & Weekday & Weekend & Weekday & Weekend & Weekday & Weekend \\
\hline Paid work or study & 26 & 17 & 18 & 5 & 26 & $\overline{11}$ & 28 & 13 \\
\hline Unpaid work & 11 & 13 & 14 & 15 & 11 & 14 & 9 & 10 \\
\hline Personal care & 48 & 50 & 50 & 57 & 45 & 48 & 45 & 50 \\
\hline Leisure & 15 & 19 & 17 & 23 & 16 & 23 & 18 & 26 \\
\hline Other & 1 & 1 & 0 & 1 & 2 & 3 & 1 & 2 \\
\hline
\end{tabular}

Source: Secretariat estimates based on national time-use surveys (see Table A1.2 for more details).

\section{A1.6. Recording of simultaneous activities}

58. Surveys also differ in how and if they record activities that are performed simultaneously. Generally, the data are coded as to show people engaged in one activity at a time. For some countries, however, surveys include separate questions designed to learn about simultaneous activities (i.e. watching television while cooking or supervising children while ironing clothes), which allows a distinction between "primary" and "secondary" activities. One limitation is that "primary" activities are meticulously tracked while "secondary" ones are usually overlooked. A further element affecting the comparability of estimates for secondary activities is whether activities that typically require only a few minutes of one's time, i.e. moving a load of laundry from the washer to the dryer, are reported consistently enough to produce comparable estimates of time devoted to them. This in turn depends on the length of the time slots in which respondents can report their activities, ranging from 1 minute in the United States to 15 minutes in Ireland and Japan. 
DELSA/ELSA/WD/SEM(2011)1

Table A1.2 Methodological documentation of national time-use surveys

\begin{tabular}{|c|c|c|c|c|c|c|c|c|c|}
\hline Country & Name of Survey & Agency & Period of Assessment & Population Covered & $\begin{array}{l}\text { Sample } \\
\text { Size }\end{array}$ & Diary Days & \begin{tabular}{|l|} 
Time \\
interval
\end{tabular} & Remarks & \begin{tabular}{|l|} 
Class ification \\
activities
\end{tabular} \\
\hline Australia & Time Use Survey & $\begin{array}{l}\text { Australian } \\
\text { Bureau of } \\
\text { Statistics }\end{array}$ & $\begin{array}{l}\text { Four 13-day periods in } \\
2006 \text { containing a } \\
\text { representative proportion } \\
\text { of public holidays and } \\
\text { school holidays }\end{array}$ & $\begin{array}{l}\text { People aged } 15 \text { years and over living } \\
\text { in private dw ellings (excluding people } \\
\text { living in very remote and non-private } \\
\text { dw ellings, households containing non- } \\
\text { Australians and indigenous } \\
\text { Communities) }\end{array}$ & \begin{tabular}{|l|}
6961 \\
individuals \\
(3 643 \\
households)
\end{tabular} & \begin{tabular}{|l|}
2 consecutive \\
days
\end{tabular} & $\begin{array}{l}5 \\
\text { minutes }\end{array}$ & & 61 categories \\
\hline Austria & Time Use Survey & $\begin{array}{l}\text { Statistics } \\
\text { Austria }\end{array}$ & $\begin{array}{l}\text { End of March } 2008 \text { - } \\
\text { Beginning of April } 2009\end{array}$ & $\begin{array}{l}\text { Individuals aged } 10 \text { and over living in } \\
\text { private households }\end{array}$ & $\begin{array}{l}8234 \\
\text { individuals }\end{array}$ & 1 day & $\begin{array}{l}15 \\
\text { minutes }\end{array}$ & $\begin{array}{l}\text { - The time span betw een } 11 \mathrm{pm} \\
\text { and } 5 \text { am is } 30 \text { minutes }\end{array}$ & 420 categories \\
\hline Belgium & \begin{tabular}{|l|} 
Harmonised \\
European Time Use \\
Survey (HETUS)
\end{tabular} & $\begin{array}{l}\text { EUROSTAT } \\
\text { and NSO }\end{array}$ & $\begin{array}{l}\text { January } 2005 \text { - January } \\
2006\end{array}$ & $\begin{array}{l}\text { Tw o survey populations: (1) } \\
\text { Individuals aged } 12 \text { years old or older } \\
\text { belonging to the Belgian population } \\
\text { and living in private households; (2) } \\
\text { private households (each including all } \\
\text { individuals living in it) }\end{array}$ & \begin{tabular}{|l|}
6412 \\
individuals \\
$(3474$ \\
households $)$
\end{tabular} & $\begin{array}{l}1 \text { w eekday }+ \\
1 \text { w eekend } \\
\text { day }\end{array}$ & $\begin{array}{l}10 \\
\text { minutes }\end{array}$ & & 49 categories \\
\hline Canada & $\begin{array}{l}\text { General Social } \\
\text { Survey (special } \\
\text { module) }\end{array}$ & $\begin{array}{l}\text { Statistics } \\
\text { Canada }\end{array}$ & \begin{tabular}{|l|}
11 monthly samples of \\
equal size from January to \\
November 2005 (extended \\
to mid-December)
\end{tabular} & $\begin{array}{l}\text { - Residents aged } 15 \text { and older in } \\
\text { private households (except those } \\
\text { living in the Yukon, Nunavut and } \\
\text { Northw est Territories) }\end{array}$ & $\begin{array}{l}19597 \\
\text { individuals }\end{array}$ & 1 day & $\begin{array}{l}5 \\
\text { minutes }\end{array}$ & $\begin{array}{l}\text { The exclusion of the second half } \\
\text { of December (Christmas holidays) } \\
\text { may bias time-use estimates }\end{array}$ & 182 categories \\
\hline China & Time Use Survey & $\begin{array}{l}\text { National } \\
\text { Bureau of } \\
\text { Statistics of } \\
\text { China }\end{array}$ & May 2008 & Persons aged 15-74 & \begin{tabular}{|l|}
37142 \\
individuals \\
$(16661$ \\
households $)$
\end{tabular} & $\begin{array}{l}1 \text { w eekday }+ \\
1 \text { w eekend } \\
\text { day }\end{array}$ & $\begin{array}{l}10 \\
\text { minutes }\end{array}$ & $\begin{array}{l}\text { The sample period is not } \\
\text { representative for the year and } \\
\text { may bias time-use estimates }\end{array}$ & 30 categories \\
\hline Denmark & Time Use Survey & $\begin{array}{l}\text { Danish Data } \\
\text { Archive }\end{array}$ & $\begin{array}{l}\text { mid January - mid } \\
\text { November } 2001\end{array}$ & $\begin{array}{l}\text { Individuals aged } 15 \text { and over living in } \\
\text { private households }\end{array}$ & $\begin{array}{l}2741 \\
\text { households }\end{array}$ & $\begin{array}{l}1 \text { w eekday + } \\
1 \text { w eekend } \\
\text { day }\end{array}$ & $\begin{array}{l}10 \\
\text { minutes }\end{array}$ & $\begin{array}{l}\text { - The sample period is not } \\
\text { representative for the year and } \\
\text { may bias time-use estimates } \cdot \text { The } \\
\text { data are unw eighted }\end{array}$ & 167 categories \\
\hline Estonia & \begin{tabular}{|l|} 
Harmonised \\
European Time Use \\
Survey (HETUS)
\end{tabular} & $\begin{array}{l}\text { EUROSTAT } \\
\text { and NSO }\end{array}$ & April 1999 - March 2000 & $\begin{array}{l}\text { Residents aged } 10 \text { and over living in } \\
\text { private households }\end{array}$ & \begin{tabular}{|l|}
5728 \\
individuals \\
$(2581$ \\
households $)$
\end{tabular} & 2 days & $\begin{array}{l}10 \\
\text { minutes }\end{array}$ & & 49 categories \\
\hline Finland & \begin{tabular}{|l|} 
Harmonised \\
European Time Use \\
Survey (HETUS)
\end{tabular} & $\begin{array}{l}\text { EUROSTAT } \\
\text { and NSO }\end{array}$ & March 1999 - March 2000 & $\begin{array}{l}\text { Tw o survey populations: (1) } \\
\text { Residents aged } 10 \text { and over living in } \\
\text { private households; (2) households }\end{array}$ & $\left|\begin{array}{l}5332 \\
\text { individuals } \\
\left(\begin{array}{l}3 \\
0\end{array} 11\right. \\
\text { households })\end{array}\right|$ & $\begin{array}{l}1 \text { w eekday + } \\
1 \text { w eekend } \\
\text { day }\end{array}$ & $\begin{array}{l}10 \\
\text { minutes }\end{array}$ & & 49 categories \\
\hline
\end{tabular}


DELSA/ELSA/WD/SEM(2011)1

\begin{tabular}{|c|c|c|c|c|c|c|c|c|c|}
\hline Country & Name of Survey & Agency & Period of Assessment & Population Covered & $\begin{array}{l}\text { Sample } \\
\text { Size }\end{array}$ & Diary Days & \begin{tabular}{|l|} 
Time \\
interval
\end{tabular} & Other Data Features & Classification \\
\hline France & \begin{tabular}{|l|} 
Harmonised \\
European Time Use \\
Survey (HETUS)
\end{tabular} & $\begin{array}{l}\text { EUROSTAT } \\
\text { and NSO }\end{array}$ & \begin{tabular}{|l|} 
February 1998 - February \\
1999 (except 4-18 August \\
and 21 December - 4 \\
January)
\end{tabular} & $\begin{array}{l}\text { Persons aged } 15 \text { and over living in } \\
\text { private households, sampling unit is } \\
\text { the household }\end{array}$ & \begin{tabular}{|l|}
15441 \\
individuals \\
$(12000$ \\
households $)$
\end{tabular} & 1 day & \begin{tabular}{|l|}
10 \\
minutes
\end{tabular} & $\begin{array}{l}\text { The sample period is not } \\
\text { representative for the year and } \\
\text { may bias time-use estimates }\end{array}$ & 49 categories \\
\hline Germany & \begin{tabular}{|l|} 
Harmonised \\
European Time Use \\
Survey (HETUS)
\end{tabular} & $\begin{array}{l}\text { EUROSTAT } \\
\text { and NSO }\end{array}$ & $\begin{array}{l}\text { April } 2001 \text { - end March } \\
2002 \text { (May 2002) }\end{array}$ & $\begin{array}{l}\text { All private households including } \\
\text { individuals aged } 10 \text { and older, } \\
\text { excluding persons w ithout a fixed } \\
\text { abode and individuals living in group } \\
\text { quarters and similar institutions } \\
\text { (military barracks, institutions for the } \\
\text { retired, etc.) }\end{array}$ & \begin{tabular}{|l|}
10051 \\
individuals \\
$(5443$ \\
households $)$
\end{tabular} & $\begin{array}{l}2 \text { w eekdays }+ \\
1 \text { w eekend } \\
\text { day }\end{array}$ & $\begin{array}{l}10 \\
\text { minutes }\end{array}$ & & 49 categories \\
\hline Hungary & Time Use & $\begin{array}{l}\text { Hungarian } \\
\text { Central } \\
\text { Statistical } \\
\text { Office }\end{array}$ & $\begin{array}{l}1 \text { September } 1999 \text { - } 6 \\
\text { September } 2000\end{array}$ & $\begin{array}{l}\text { Hungarian citizens living in private } \\
\text { households betw een } 15-74 \text { years }\end{array}$ & $\begin{array}{l}11000 \\
\text { individuals }\end{array}$ & $\begin{array}{l}4 \text { days (one in } \\
\text { each season, } \\
\text { on different } \\
\text { days of the } \\
\text { w eek) }\end{array}$ & $\begin{array}{l}10 \\
\text { minutes }\end{array}$ & & 21 categories \\
\hline Ireland & $\begin{array}{l}\text { National Time-Use } \\
\text { Survey }\end{array}$ & $\begin{array}{l}\text { Economic and } \\
\text { Social } \\
\text { Research } \\
\text { Institute }\end{array}$ & $\begin{array}{l}9 \text { w eek period from } 22 \\
\text { April to } 1 \text { July } 2005\end{array}$ & Adults aged 18 and over & $\mid \begin{array}{l}1089 \\
\text { individuals } \\
(585 \\
\text { households })\end{array}$ & $\begin{array}{l}1 \text { w eekday }+ \\
1 \text { w eekend } \\
\text { day }\end{array}$ & $\begin{array}{l}15 \\
\text { minutes }\end{array}$ & $\begin{array}{l}\text { - The sample period is not } \\
\text { representative for the year and } \\
\text { may bias time-use estimates } \cdot \text { Very } \\
\text { small sample size } \cdot \text { The diary } \\
\text { contains a list of } 26 \text { pre-coded } \\
\text { activity categories out of which the } \\
\text { respondents can choose } \cdot \text { Up to } 4 \\
\text { simultaneous activities can be } \\
\text { choosen }\end{array}$ & 26 categories \\
\hline Italy & \begin{tabular}{|l|} 
Harmonised \\
European Time Use \\
Survey (HETUS)
\end{tabular} & $\begin{array}{l}\text { EUROSTAT } \\
\text { and NSO }\end{array}$ & April 2002 - March 2003 & $\begin{array}{l}\text { All members of households residing in } \\
\text { Italy aged over } 3 \text { and including the } \\
\text { elderly (no upper age limit) }\end{array}$ & $\mid \begin{array}{l}47589 \\
\text { individuals } \\
(21000 \\
\text { households })\end{array}$ & 1 day & $\begin{array}{l}10 \\
\text { minutes }\end{array}$ & & 49 categories \\
\hline
\end{tabular}


DELSA/ELSA/WD/SEM(2011)1

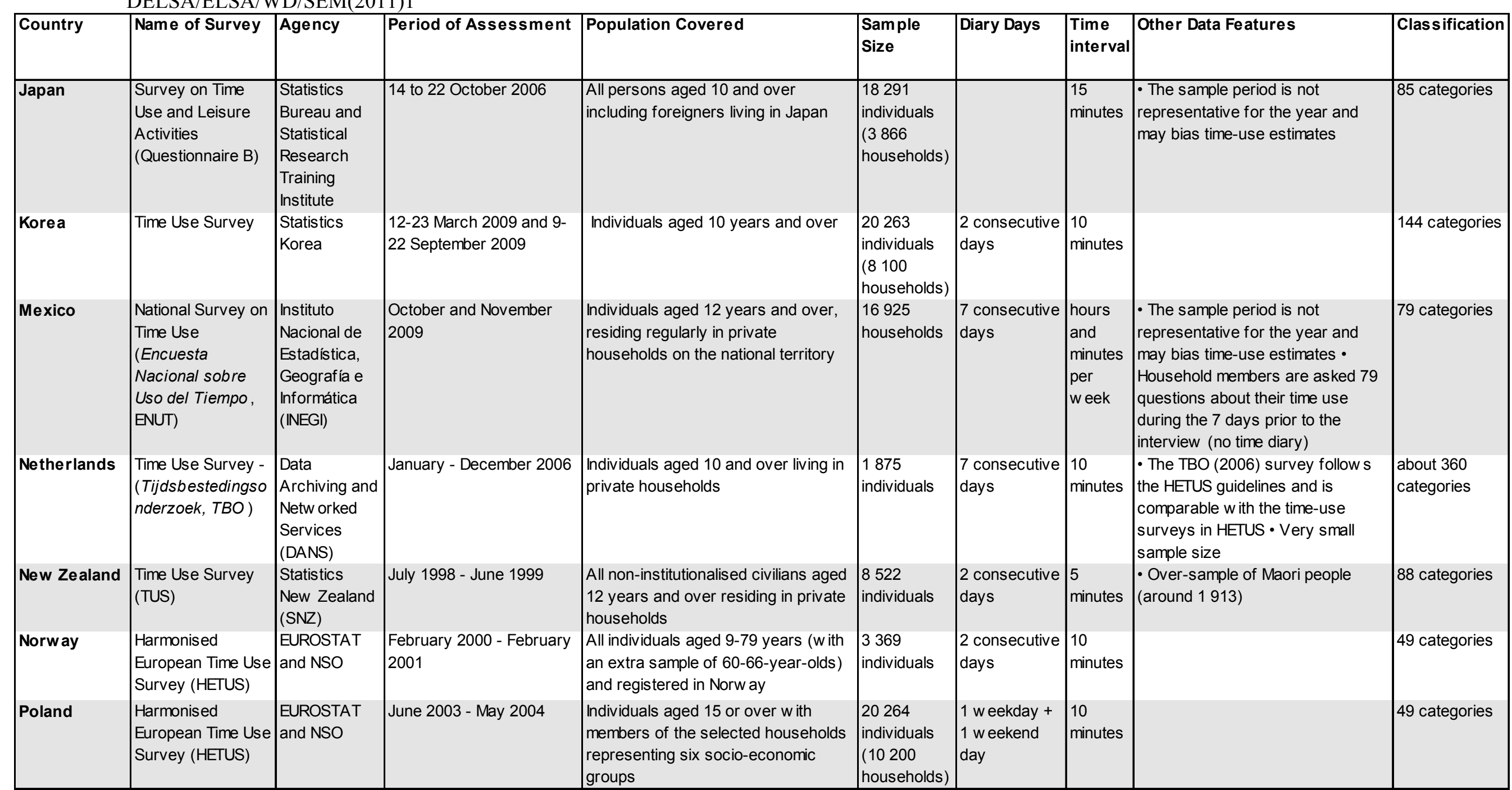


DELSA/ELSA/WD/SEM(2011)1

\begin{tabular}{|c|c|c|c|c|c|c|c|c|c|}
\hline Country & Name of Survey & Agency & Period of Assessment & Population Covered & $\begin{array}{l}\text { Sample } \\
\text { Size }\end{array}$ & Diary Days & \begin{tabular}{|l|} 
Time \\
interval
\end{tabular} & Other Data Features & Classification \\
\hline Portugal & Time Use Survey & \begin{tabular}{|l} 
Statistics \\
Portugal
\end{tabular} & October - November 1999 & $\begin{array}{l}\text { Individuals aged } 15 \text { or over living in } \\
\text { private households }\end{array}$ & $\begin{array}{l}5500 \\
\text { households }\end{array}$ & 1 day & $\begin{array}{l}10 \\
\text { minutes }\end{array}$ & $\begin{array}{l}\text { - It } w \text { as intended to follow HETUS } \\
\text { guidelines, but budget restrictions } \\
\text { implied a tw o-month collection } \\
\text { period, and a simplified } \\
\text { questionnaire }\end{array}$ & 77 categories \\
\hline Slovenia & $\begin{array}{l}\text { Harmonised } \\
\text { European Time Use } \\
\text { Survey (HETUS) }\end{array}$ & $\begin{array}{l}\text { EUROSTAT } \\
\text { and NSO }\end{array}$ & April 2000 - March 2001 & $\begin{array}{l}\text { Individuals aged } 10 \text { or over living in } \\
\text { private households }\end{array}$ & \begin{tabular}{|l|}
6190 \\
individuals \\
$(4500$ \\
households $)$
\end{tabular} & $\begin{array}{l}1 \text { w eekday }+ \\
1 \text { w eekend } \\
\text { day }\end{array}$ & $\begin{array}{l}10 \\
\text { minutes }\end{array}$ & & 49 categories \\
\hline South Africa & Time Use Survey & $\begin{array}{l}\text { Statistics } \\
\text { South Africa }\end{array}$ & $\begin{array}{l}3 \text { rounds: February, June } \\
\text { and October } 2000\end{array}$ & $\begin{array}{l}\text { Individuals aged } 10 \text { or over living in } \\
\text { private households }\end{array}$ & $\begin{array}{l}14553 \\
\text { individuals } \\
(8564 \\
\text { households })\end{array}$ & 1 day & $\begin{array}{l}10 \\
\text { minutes }\end{array}$ & $\begin{array}{l}\text { The three-rounds approach was } \\
\text { adopted so as to capture possible } \\
\text { seasonal variations in activity, but } \\
\text { they are unlikely to be fully } \\
\text { representative for the year and } \\
\text { may bias time-use estimates }\end{array}$ & 99 categories \\
\hline Spain & $\begin{array}{l}\text { Harmonised } \\
\text { European Time Use } \\
\text { Survey (HETUS) }\end{array}$ & $\begin{array}{l}\text { EUROSTAT } \\
\text { and NSO }\end{array}$ & $\begin{array}{l}\text { October } 2002 \text { - September } \\
2003\end{array}$ & $\begin{array}{l}\text { All members aged } 10 \text { or older of } \\
\text { regular resident households }\end{array}$ & \begin{tabular}{|l|}
46774 \\
individuals \\
$(17700$ \\
households $)$
\end{tabular} & 1 day & $\begin{array}{l}10 \\
\text { minutes }\end{array}$ & & 49 categories \\
\hline Sweden & \begin{tabular}{|l} 
Harmonised \\
European Time Use \\
Survey (HETUS)
\end{tabular} & $\begin{array}{l}\text { EUROSTAT } \\
\text { and NSO }\end{array}$ & $\begin{array}{l}\text { October } 2000 \text { - September } \\
2001\end{array}$ & $\begin{array}{l}\text { Individuals aged } 20-84 \text { registered in } \\
\text { Sw eden during the survey period }\end{array}$ & \begin{tabular}{|l|}
3998 \\
individuals \\
$(2138$ \\
households $)$
\end{tabular} \mid & $\begin{array}{l}1 \text { w eekday }+ \\
1 \text { w eekend } \\
\text { day }\end{array}$ & $\begin{array}{l}10 \\
\text { minutes }\end{array}$ & & 49 categories \\
\hline Turkey & Time Use Survey & $\begin{array}{l}\text { Turkish } \\
\text { Statistical } \\
\text { Institute } \\
\text { (TURKSTAT) }\end{array}$ & January - December 2006 & $\begin{array}{l}\text { Non-institutionalised population aged } \\
15 \text { years and over living w ithin the } \\
\text { borders of Turkey }\end{array}$ & 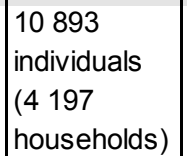 & $\begin{array}{l}1 \text { w eekday }+ \\
1 \text { w eekend } \\
\text { day }\end{array}$ & $\begin{array}{l}10 \\
\text { minutes }\end{array}$ & & 27 categories \\
\hline $\begin{array}{l}\text { United } \\
\text { Kingdom }\end{array}$ & $\begin{array}{l}\text { Harmonised } \\
\text { European Time Use } \\
\text { Survey (HETUS) }\end{array}$ & $\begin{array}{l}\text { EUROSTAT } \\
\text { and NSO }\end{array}$ & June 2000 - July 2001 & $\begin{array}{l}\text { All members aged } 10 \text { and over in a } \\
\text { selected household }\end{array}$ & $\begin{array}{l}9590 \\
\text { individuals }\end{array}$ & $\begin{array}{l}1 \text { w eekday }+ \\
1 \text { w eekend } \\
\text { day }\end{array}$ & $\begin{array}{l}10 \\
\text { minutes }\end{array}$ & & 49 categories \\
\hline United States & $\begin{array}{l}\text { American Time Use } \\
\text { Survey (ATUS) }\end{array}$ & $\begin{array}{l}\text { Bureau of } \\
\text { Labor } \\
\text { Statistics } \\
\text { (BLS) }\end{array}$ & January - December 2008 & $\begin{array}{l}\text { People aged } 15 \text { and over living in } \\
\text { private households }\end{array}$ & $\begin{array}{l}12723 \\
\text { individuals }\end{array}$ & 1 day & 1 minute & & $\begin{array}{l}\text { about } 400 \\
\text { categories }\end{array}$ \\
\hline
\end{tabular}

